\title{
Influence of underwater light climate on periphyton and phytoplankton communities in shallow lakes from the Pampa plain (Argentina) with contrasting steady states
}

\author{
María Laura SÁNCHEZ, ${ }^{1,2 *}$ Gonzalo Luis PÉREZ, ${ }^{1,3}$ Irina IZAGUIRRE, ${ }^{1,2}$ Haydée PIZARRO ${ }^{1,2}$ \\ ${ }^{1}$ Consejo Nacional de Investigaciones Científicas y Técnicas (CONICET), Buenos Aires, Argentina; ${ }^{2}$ Laboratorio de Limnología, \\ Departamento de Ecología, Genética y Evolución, Facultad de Ciencias Exactas y Naturales, Universidad de Buenos Aires, Argentina; \\ ${ }^{3}$ Laboratorio de Ecología y Fotobiología Acuática, Instituto de Investigaciones Biotecnológicas-Instituto Tecnológico de Chascomús, \\ Chascomús (IIB-INTECH), Argentina. \\ *Corresponding author: laurasanchez@ege.fcen.uba.ar
}

\begin{abstract}
Shallow lakes from the Pampa plain (Argentina) are subjected to the impact of different human activities, and as a consequence, most of them are in a turbid state. Three types of shallow lakes have been described in this region: clear-vegetated, phytoplanktonturbid and inorganic-turbid. We analysed the periphyton and phytoplankton structure in five selected shallow lakes with contrasting optical characteristics. In the case of periphyton, we studied the variation in depth. Pigment compositions of both algal communities were analysed by means of high-performance liquid chromatography. Additionally, we studied the taxonomic algal composition of both communities and the mass variables of periphyton. We observed a general decreasing pattern in the mean values of periphytic abundance with depth, and stratification in periphyton was generally consistent with the vertical profiles of pigments. Relationships between cell counts and pigments also suggested changes in the intracellular pigment concentration due to photoacclimation. In clear lakes, surface periphytic communities were co-dominated by chlorophytes and diatoms. In turbid lakes the surface assemblages were mainly represented by diatoms and the relative contribution of cyanobacteria increased with depth. The interaction between light and nutrients in different turbid scenarios may explain the patterns observed in the development of the periphytic community. We observed lower periphyton accrual in lakes that presented boundary values in the restrictions of either nutrients or light availability. In phytoplanktonturbid lakes, periphyton exhibited a considerable growth due to the rich nutrient conditions, but the community was dominated by the heterotrophic fraction and we also found algal groups well adapted to light limitation.
\end{abstract}

Key words: periphyton, phytoplankton, pigment composition, clear shallow lakes, turbid shallow lakes, HPLC.

Received: February 2012. Accepted: June 2012.

\section{INTRODUCTION}

Autotrophic organisms collect light energy from the underwater light field by means of photosynthetic pigments. The absorption of these molecules ranges between 400 and $700 \mathrm{~nm}$ (photosynthetically active radiation) (PAR) and different wavelengths are used with dissimilar efficiencies (Kirk, 1994). Photosynthesis is divided into two sets of light reaction: photosystem I and photosystem II. Each photosystem is constituted by a core of chlorophyll $a$ (Chl $a$ ) assembly with light-absorbing molecules that function like antennae besides $\mathrm{Chl} a$ : they could be chlorophyll $b(\mathrm{Chl} b)$, chlorophyll $c(\mathrm{Chl} c)$, carotenoids and billiproteins (Hill, 1996). These accessory pigments extend absorption still further (Kirk, 1994). The composition of these photosystems varies amongst the different taxonomic algal groups and Cyanobacteria.

The phytoplankton community has different strategies to avoid light limitation. These strategies include regulating their position in the water column (by changing their buoyancy or flagellar motility) (Falkowski and Raven, 2007), increasing the cell-specific light-harvesting capacity, and increasing the complement of accessory photosynthetic pigments (both process characteristic of photoacclimation) (Falkowski and LaRoche, 1991). On the other hand, the effect of light on freshwater attached algae has been comparatively less studied than that on phytoplankton (Hill, 1996). Some studies have demonstrated that attached algae are often capable of migrating from the surface into the bottom and vice versa within the own matrix of the community (Falkowski and Raven, 2007). Other studies have shown adaptations or acclimations to shade, possibly by means of an increase in antenna pigments (Hill, 1996).

In shallow lakes, the permanent mixing of the water column allows phytoplankton to access to depths with better light conditions (Reynolds, 1994), while the periphytic community has to adapt to the light regimes both in clear and turbid shallow lakes considering its attached habit. Periphytic algae have competitive interactions with phy- 
toplankton when light is limiting: phytoplankton has access to light first and thus reduces the availability of this resource for periphyton (Hansson, 1988).

According to the model proposed by Scheffer et al. (1993), shallow lakes present two alternative stable states: a turbid state, with high abundances of phytoplankton and lacking of submerged macrophytes (hereafter phytoplankton-turbid lakes), and a clear state with abundant submerged vegetation. Over a range of nutrient concentrations, the shift between clear and turbid states is due to several mechanisms, most of them centred in the interaction between submerged vegetation and phytoplankton.

In South America, the Pampa plain contains an extended wetland formed by numerous clear and turbid shallow lakes that fit in the model proposed by Scheffer et al. (1993). In addition, a third type was observed in this geographic region: inorganic-turbid shallow lakes with high turbidity due to suspended inorganic material (Quirós et al., 2002; Allende et al., 2009). Since the underwater light availability varies greatly amongst the different types of shallow lakes of the Pampa region and even amongst turbid lakes with different kinds of particulate matter (Pérez et al., 2010), a great variability of optical scenarios is present in the same area.

There are several studies about phytoplankton composition in relation to the optical characteristics and physicochemical properties of the shallow lakes from the Pampa plain (Izaguirre and Vinocur 1994a, 1994b; Allende et al., 2009; Pérez et al., 2010; Izaguirre et al., 2012). However, the information about the periphyton community of this region is still scarce (e.g., Cano et al., 2008; Casco et al., 2009). In a recent study, we compared the periphyton community with phytoplankton under contrasting optical scenarios, and found that in a clear-vegetated lake the algal fraction of periphyton was dominant (Sánchez et al., 2010).

The aim of this work was to analyse the periphyton and phytoplankton communities growing on the different types of shallow lakes present in the Pampa plain. We investigated the pigment composition of both communities and the adaptation processes in lakes with contrasting light climates. Within this framework, we postulate two hypotheses: i) taxonomical and pigment composition of the algal periphyton differs amongst shallow lakes with different optical scenarios; ii) the biomass and structure of the algal periphyton vary along depth in each shallow lake.

\section{METHODS}

\section{Study site}

We selected five shallow lakes in the Pampa plain, located in Buenos Aires province (Argentina). Except for Kakel Huincul, the other four shallow lakes belong to the Salado river floodplain (Fig. 1). The lakes of this region are classified as eutrophic or hypereutrophic (Quirós et al., 2002), and are polymictic (Allende et al., 2009). This diversity of shallow lakes may be directly linked with the land use, mainly with agricultural activities, which have shown a fast growth in the region in the last decades. The intensive use of fertilisers and pesticides has caused degradation in the Pampean wetland, and increasing nutrient load input to the eutrophic shallow lakes (Quirós et al., 2006). In areas of intense land use, most shallow lakes have turned from clear to turbid, as pointed out by Quirós et al. $(2002,2006)$.

The experiments were run in the littoral zone of the five shallow lakes. The selection of the lakes was based on their different optical conditions, so as to comprise the three types of optical scenarios described in the region: phytoplankton-turbid shallow lakes (El Burro: $35^{\circ} 42^{\prime} \mathrm{S}$; $57^{\circ} 55^{\prime} \mathrm{W}$; San Jorge: $35^{\circ} 40^{\prime} \mathrm{S}$; $57^{\circ} 47^{\prime} \mathrm{W}$ ); inorganicturbid shallow lake (Yalca: $35^{\circ} 35^{\prime} \mathrm{S}$; $57^{\circ} 55^{\prime} \mathrm{W}$ ); and clear-vegetated shallow lakes (El Triunfo: $35^{\circ} 51^{\prime}$ S; $57^{\circ}$ 52' W; Kakel Huincul: $36^{\circ} 48^{\prime} \mathrm{S}$; $57^{\circ} 47^{\prime} \mathrm{W}$ ). Tab. 1 shows the main morphometric features of the shallow lakes under study.

\section{Experimental design}

On the basis of the characteristics of the shallow lakes of the region (Allende et al., 2009), we selected representative sites of the littoral zone of each shallow lake to install the artificial substrata and to take the different samples. For periphyton analysis, we used artificial substrata (at least six polycarbonate strips of $3 \times 70 \mathrm{~cm}$ ), placed vertically in triplicate in the littoral zone of each lake for one month (from 5-6 November to 5-6 December 2007) (depending on the location of each lake), for the colonisation of the community. Although the use of artificial substrata implies lost of certain degree of realism, there is abundant literature applying this methodology since it allows a better quantification of its components (Meier et al., 1983; Hansson, 1988; Kalff, 2003; Rodríguez et al., 2012).

Once colonised, the substrata were removed from the lakes, cut and divided into sections of $10 \mathrm{~cm}$. The upper $10 \mathrm{~cm}$ and the deeper $10 \mathrm{~cm}$ of each polycarbonate strip were discarded to study only the portions that were always in contact with the water column and were not influenced by the bottom sediments. We obtained a profile of $50 \mathrm{~cm}$ depth in all lakes except for Kakel Huincul, where the hydrometric level allowed only a profile of $40 \mathrm{~cm}$. Additionally, on December 5-6, we sampled the phytoplankton integrated in the water column, using an ad hoc sampling bottle in each lake.

\section{Physical and chemical data}

The following physical and chemical variables were 


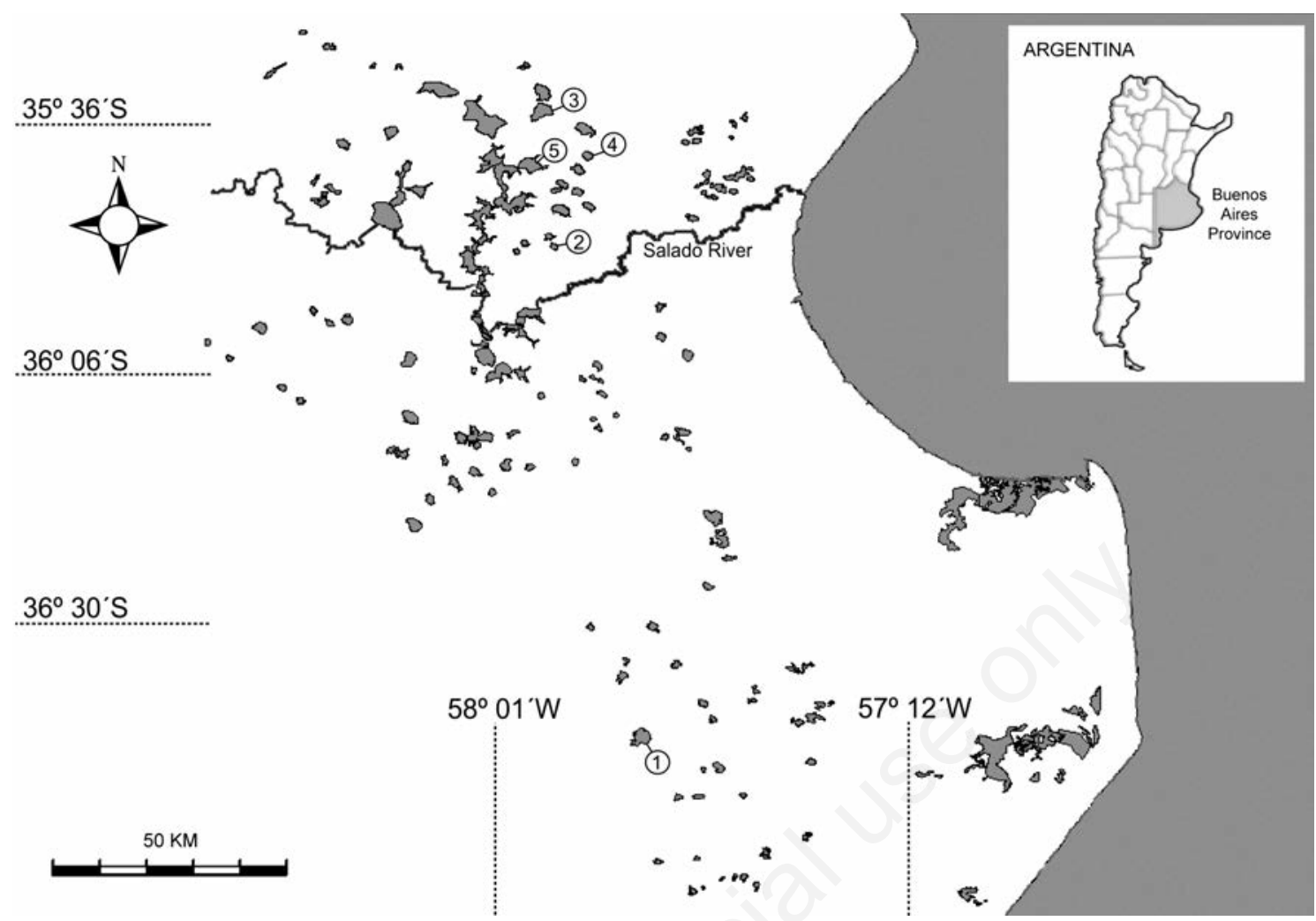

Fig. 1. Map of the area where the shallow lakes under study are located. Clear-vegetated lakes: Kakel Huincul (1), El Triunfo (2); inorganic-turbid lake: Yalca (3); phytoplankton-turbid lakes: San Jorge (4), El Burro (5).

Tab. 1. Phytoplankton $\mathrm{Chl} a$, physical, chemical and morphometric variables characterising the trophic and optical state of the five shallow lakes studied. Values in brackets correspond to November and December 2007, while unique values correspond to December 2007 only.

\begin{tabular}{|c|c|c|c|c|c|}
\hline & \multicolumn{2}{|c|}{ Clear-vegetated } & \multicolumn{3}{|c|}{ Turbid } \\
\hline & \multirow[b]{2}{*}{ Kakel Huincul } & \multirow[b]{2}{*}{ El Triunfo } & \multicolumn{2}{|c|}{ Phytoplankton } & \multirow{2}{*}{$\begin{array}{l}\text { Inorganic } \\
\text { Yalca }\end{array}$} \\
\hline & & & El Burro & San Jorge & \\
\hline Area $\left(\mathrm{km}^{2}\right)$ & 29.5 & 1.5 & 10.2 & 3.0 & 10.6 \\
\hline Maximum depth (m) & 4 & n.a. & n.a. & n.a. & 1.4 \\
\hline Mean depth $(\mathrm{m})$ & 1.8 & n.a. & 1.8 & n.a. & 0.5 \\
\hline Shore line $(\mathrm{km})$ & 32.2 & 5.1 & n.a. & 7.4 & 16.2 \\
\hline Sampling depth (m) & 1.20 & 1.25 & 0.63 & 0.72 & 0.70 \\
\hline $\mathrm{pH}$ & $(7.9-7.4)$ & $(9.4-9.1)$ & $(8.6-8.9)$ & $(8.9-8.7)$ & $(8.1-8.4)$ \\
\hline Conductivity $\left(\mathrm{mS} \mathrm{cm}^{-1}\right)$ & $(1.15-1.30)$ & $(1.86-1.54)$ & $(1.35-1.46)$ & $(1.54-1.59)$ & $(0.69-0.77)$ \\
\hline $\mathrm{DO}\left(\mathrm{mg} \mathrm{L}^{-1}\right)$ & $(6.2-6.2)$ & $(18.1-11.6)$ & $(10.4-10.1)$ & $(9.2-7.2)$ & $(8.3-7.2)$ \\
\hline Temperature $\left({ }^{\circ} \mathrm{C}\right)$ & $(15.9-22.7)$ & $(21.0-25.4)$ & $(18.8-24.8)$ & $(17.8-21.0)$ & $(17.3-22.0)$ \\
\hline Phyto Chl $a\left(\mu \mathrm{g} \mathrm{L}^{-1}\right)$ & $(3.27-1.93)$ & $(65.32-21.07)$ & $(188.04-93.06)$ & $(238.05-207.64)$ & $(11.14-16.33)$ \\
\hline DIN $\left(\mu g-N^{-1}\right)$ & 18.6 & 13.79 & 30 & 24 & 53 \\
\hline $\operatorname{SRP}\left(\mu \mathrm{g} \mathrm{L}^{-1}\right)$ & 6.2 & 63 & 40 & 17.8 & 336 \\
\hline $\mathrm{TP}\left(\mu \mathrm{g} \mathrm{L}^{-1}\right)$ & 20 & 168 & - & 198 & 570 \\
\hline $\operatorname{TSS}\left(\mathrm{mg} \mathrm{L}^{-1}\right)$ & $(4.05-2.4)$ & $(27.5-10.8)$ & $(157-93)$ & $(60.5-61.5)$ & $(533-299)$ \\
\hline OSS (mg L $\left.{ }^{-1}\right)$ & $(5.74-2.4)$ & $(23.5-10.8)$ & $(76-51)$ & $(49-43)$ & $(86-49)$ \\
\hline Turbidity (NTU) & 1.45 & 9.48 & 66.9 & 74.9 & 316 \\
\hline $\mathrm{Kd}_{\mathrm{PAR}}\left(\mathrm{m}^{-1}\right)$ & 3.3 & 6.1 & 9.6 & 9.4 & 45.1 \\
\hline Euphotic depth $(\mathrm{cm})$ & 139.5 & 75.5 & 48.0 & 49.0 & 10.2 \\
\hline$a_{d}(P A R)\left(m^{-1}\right)$ & 0.18 & 0.62 & 1.44 & 1.16 & 10.11 \\
\hline $\mathrm{a}_{\mathrm{ph}}(\mathrm{PAR})\left(\mathrm{m}^{-1}\right)$ & 0.09 & 0.42 & 1.35 & 2.78 & 1.05 \\
\hline$a_{g}(P A R)\left(m^{-1}\right)$ & 2.55 & 3.94 & 1.21 & 1.31 & 21.9 \\
\hline
\end{tabular}

DO, dissolved oxygen; Phyto Chl a, phytoplankton Chlorophyll a; DIN, dissolved inorganic nitrogen; SRP, soluble reactive phosphorus; TP, total phosphorus; TSS, total suspended solids; OSS, organic suspended solids; Kd $d_{P A R}$, vertical diffuse attenuation coefficients for PAR; PAR, photosynthetically active radiation; Euphotic depth, 4.6/Kd $d_{P A R} ; a_{d}(P A R)$, absorption coefficients of other algal cell components, heterotrophic organisms, detritus, and inorganic particles; $a_{p h}(P A R)$, absorption coefficients of within-cell chlorophyll and accessory pigments; $a_{g}(P A R)$, absorption coefficients of chromophoric dissolved organic matter. 
measured in each lake: $\mathrm{pH}$, conductivity, dissolved oxygen and temperature. These variables were measured by portable electronic metres Hanna HI9143 and HI991301 (Hanna Instruments, Smithfield, RI, USA).

Vertical profiles of downward irradiance (spectrum $380-750 \mathrm{~nm}$ ) were obtained around noon using a spectroradiometre USB2000 (Ocean Optics ${ }^{\circledR}$, Dunedin, FL) attached to an optical fibre and a teflon diffuser. To minimise the interference due to wave action and the macrophyte cover producing shade, the measurements were performed inside a black plastic container $(50 \times 50 \times 40 \mathrm{~cm})$. The magnitudes of wave induced errors in irradiance measurements are substantial in highly turbid lakes, where light is attenuated to less than $1 \%$ of incident irradiance within $50 \mathrm{~cm}$. The device was filled with freshly collected lake water samples, which were gently shaken before measurements. Comparable methodologies have been applied to solve similar problems in the direct measurement of light attenuation coefficients in water bodies (Belmont et al., 2007; V-Balogh et al., 2009). The utility of black container was verified by comparing measurements made in situ (under suitable conditions) with those performed in the device. Light attenuation measurements carried out in situ and with the device yielded highly comparable results, within 1-10\% deviation.

Vertical diffuse attenuation coefficients for PAR $\left(\mathrm{Kd}_{\mathrm{PAR}}\right)$ were determined from the slope of the linear regression of the natural logarithm of downward irradiance profiles $v s$ depth. Obtained $\mathrm{Kd}_{\mathrm{PAR}}$ values were used to estimate the percentage of incident PAR irradiance at different layers throughout a $1.4 \mathrm{~m}$ water column depth. The thickness of the euphotic depth $\left(Z_{\text {eu }}\right)$ was calculated as $4.6 / \mathrm{Kd}_{\mathrm{PAR}}$ (Kirk, 1994).

Nephelometric turbidity (as a proxy for scattering) was measured using a bench-top 2100P (HACH Company, Loveland, $\mathrm{CO}$ ) turbidimetre calibrated against formazin liquid standards (HACH Company).

Absorption coefficients of chromophoric dissolved organic matter (CDOM) $[\mathrm{ag}(\lambda)]$ were assessed by measuring the absorbance of filtered $(0.22 \mu \mathrm{m})$ water samples from 380 to $750 \mathrm{~nm}$, at $1 \mathrm{~nm}$ intervals. CDOM absorbance $\left(A_{\text {filtrate }}\right)$ was measured in $0.01 \mathrm{~m}$ quartz cuvettes against an ultrapure water blank, using a Hitachi U-2000 spectrophotometre. (Hitachi Ltd., Tokyo, Japan) The CDOM absorbance at $750 \mathrm{~nm}$ is assumed to be zero. Therefore, in order to minimise potential errors and differences between sample and reference filter (Shooter et al., 1998), $A_{\text {filtrate }}(750 \mathrm{~nm})$ was subtracted to the entire spectra (i.e. all spectra were set to 0 at $750 \mathrm{~nm}$ ).

The CDOM absorption coefficients [ag $(\lambda)]$ were calculated as:

$$
\operatorname{ag}(\lambda)=\frac{2.303 \times A_{\text {filtrate }}(\lambda)}{r}
$$

where the $A_{\text {filtrate }}(\lambda)$ is the absorbance at wavelength $\lambda$ and $r$ is the cuvette path length in metres (Kirk, 1994).

In addition, absorption spectra by particles $\left[\mathrm{a}_{\mathrm{p}}(\lambda)\right]$ were determined using the filter-pad technique (Trüper and Yentsch, 1967) on the material collected onto GF/F filters. In order to minimise light scattering, the wet filters were placed on the sensor end of the Hitachi U-2000 spectrophotometre (Hitachi), and measured against a blank clean filter, wetted with ultrapure water.

For particulate absorption coefficients, null point correction was also applied. The common assumption is that particulate absorbance in the near-infrared is negligible. Thus, any detectable signal (apparent absorbance) is related to residual scattering and differences between sample and reference filters. Therefore, when calculating particulate absorption, $A_{\text {fiter }}$ is commonly corrected by subtracting $A_{\text {filter }}$ (750) to the whole spectrum (Cleveland and Weidemann, 1993; Shooter et al., 1998).

The absorption coefficients were estimated according to Mitchell and Kiefer (1984).

$$
a p(\lambda)=\frac{2.303 \times A_{\text {fitter }}(\lambda) \times s}{V_{\text {fit }} \times \beta(\lambda)}
$$

where $s$ is the clearance area of the filter, $\mathrm{V}_{\text {filt }}$ is the volume of filtered water, and $\beta(\lambda)$ is the amplification factor vector calculated according to Bricaud and Stramski (1990). In turn, $\beta(\lambda)$ is calculated as follows:

$$
\beta(\lambda)=1.63 \times A_{\text {fitter }}(\lambda)^{-0.22}
$$

Within the particulate fraction, we further distinguished between: i) the absorption due to within-cell chlorophyll and accessory pigments [hereafter, phytoplankton absorption, $\mathrm{a}_{\mathrm{ph}}(\lambda)$ ]; and ii) the absorption due to other algal cell components, heterotrophic organisms, detritus, and inorganic particles [hereafter, non-algal absorption, $a_{d}(\lambda)$ ]. We used Kishino's method (Kishino et al., 1985 ) to estimate $a_{d}$, while phytoplankton absorption was solved as the difference between $a_{p}$ and $a_{d}$.

A water sample was collected from each lake to determine the main nutrient concentrations. Total phosphorus (TP, from unfiltered water samples) was converted to soluble reactive phosphorus (SRP) using an acid digestion with potassium persulfate. In turn, SRP was determined as molybdate reactive $\mathrm{P}$ according to standard analytical procedures (APHA, 2005). Nitrate+nitrite (cadmium reduction method) and ammonia (salicylate method) were analysed with a $\mathrm{HACH}^{\circledR} \mathrm{DR} / 2010$ spectrophotometre using the corresponding kits of $\mathrm{HACH}^{\circledR}$ reagents. Dissolved inorganic nitrogen (DIN) was calculated as nitrate + nitrite+ammonia. 
Additionally, total suspended solids (TSS) were determined by filtering 100 to $250 \mathrm{~mL}$ of water according to the type of lake, through pre-burned Whatman ${ }^{\circledR} \mathrm{GF} / \mathrm{F}$ filters (Whatman International Ltd., Maidstone, UK), and weighing the dry residue result. The content of organic matter was estimated as the difference between this dry residue and ash after $2 \mathrm{~h}$ at $550^{\circ} \mathrm{C}$ (APHA, 2005).

\section{Sampling and laboratory procedures}

\section{Periphyton}

Periphyton was sampled at different depths of each substratum. Substrata sections of $10 \mathrm{~cm}$ in length were transported in cold and dark conditions to the laboratory where the material was carefully scrapped and divided in three aliquots to analyse the different fractions of the community. An aliquot was fixed with acidified lugol ( $1 \%$ final concentration) for the quantitative analysis of the principal algal taxonomic groups. To do it, an inverted microscope was used according to Utermöhl (1958). The counting error, instead, was estimated according to Venrick (1978). To express abundances, we considered cells, filaments or colony as individuals, taking into account the average number of cells per filament and the mean colony size in the samples. A second aliquot was used to determine the pigments present. This aliquot was first filtered through Whatman ${ }^{\circledR} \mathrm{GF} / \mathrm{F}$, immediately wrapped in aluminum foil, and stored at $-80^{\circ} \mathrm{C}$ until processing (cf. below in the section High performance liquid chromatography pigment determination). A third aliquot was filtered through Whatman ${ }^{\circledR} \mathrm{GF} / \mathrm{C}$ to determine dry weight (DW) and ash-free dry weight (AFDW). Whatman ${ }^{\circledR} \mathrm{GF} / \mathrm{C}$ filters were previously precombusted at $440^{\circ} \mathrm{C}$ for $3 \mathrm{~h}$ and weighed prior to use, and DW was estimated by weighing the filtered material once dried at $60^{\circ} \mathrm{C}$ on stove. AFDW was determined as the mass difference after $3 \mathrm{~h}$ calcination $\left(440^{\circ} \mathrm{C}\right)$ of dry samples (APHA, 2005). All variables were related to areal base. In addition, the autotrophic index (AI) was estimated as the ratio AFDW/Chl $a$. An AI value higher than 200 indicates a high proportion of heterotrophic, non-chlorophyllous organisms or organic detritus (APHA, 2005).

\section{Phytoplankton}

A subsurface water sample of phytoplankton was transported in cold and dark conditions to the laboratory where it was filtered through Whatman ${ }^{\circledR} \mathrm{GF} / \mathrm{F}$ in the same way as for periphyton for pigment determination. Quantitative nano- and micro-phytoplankton samples were fixed with acidified lugol (1\% final concentration). For phytoplankton counts, we followed the same procedures described for periphyton.

\section{High performance liquid chromatography pigment determination}

Periphyton and phytoplankton pigments were estimated from triplicate samples from the material previously filtered through Whatman ${ }^{\circledR}$ GF/F. Pigments were extracted using $90 \%$ aqueous acetone and the extracts were cleared by centrifugation at $3000 \mathrm{rpm}$ for $10 \mathrm{~min}$. Pigment extracts were measured by ion pairing reverse-phase high performance liquid chromatography (HPLC) (Hurley, 1988) using an Äkta basic chromatograph (GE Healthcare Ltd., Amersham, UK) controlled by the program Unicorn (GE Healthcare Ltd.). The method used was described in Laurion et al. (2002) and modified from Mantoura and Llewellyn (1983). Standards for the identification and quantification of pigments were obtained from Fluka production $\mathrm{GmbH}$ (Buchs, Switzerland) and from the International Agency for 14C Determination (Hørsholm, Denmark). A few carotenoids for which no standards were available were identified on the basis of published retention times. In the absence of the corresponding standard, these carotenoids were quantified against fucoxanthin (fucox), or in the case of a myxoxanthophyll-like carotenoid, against myxoxanthophyll (myxo) standards. The procedure did not allow the individualisation of zeaxanthin (zeax) and lutein (lut), which are referred to as zeax+lut.

In order to study periphytic zonation with depth, we selected a group of pigments, both photosynthetic and photoprotected, as taxonomic markers. Amongst chlorophylls, xanthophylls and carotenes, $\mathrm{Chl} a$ and $\beta$-carotene ( $\beta$-carot) are characteristic of all algae (Van Den Hoek et $a l .$, 1998). Chlorophyll $b$ is characteristic of Chlorophyta and Euglenophyta, whereas lut occurs only in Chlorophyta. Myxoxanthophyll is characteristic of Cyanobacteria, and zeax is an important pigment of this division (Van Den Hoek et al., 1998). We could not identify different classes of Chromophyta. However, fucox is an important pigment of both Chrysophyceae and Bacillariophyceae, whereas diadinoxanthin (diad) is an important pigment of Xanthophyceae, Bacillariophyceae, and Chrysophyceae (Van Den Hoek et al., 1998). Alloxanthin is characteristic of Cryptophyta, but it was not identified in our samples.

In order to quantitatively compare phytoplankton and periphyton communities we used the criteria proposed by Goldsborough and Robinson (1996). We calculated the areal phytoplanktonic $\mathrm{Chl} a$ concentration considering a water column of $10 \mathrm{~m} \times 10 \mathrm{~m} \times$ sampling point depth. To obtain a unique value for periphyton community, we calculated the mean value of the periphyton $\mathrm{Chl} a$ concentration for all depths.

\section{Statistical analysis}

We analysed the statistical differences in the periphytic variables ( $\mathrm{Chl} a$, total accessory pigments, DW, 
AFDW, ash, AI, total densities) with one- and two-way ANOVA, with lakes and depth as main factors (Underwood, 1997) using STATISTICA $7^{\circledR}$ (StatSoft Inc., Tulsa, OK, USA).

\section{RESULTS}

\section{Physical and chemical data}

The morphometric and environmental variables as well as the optical characteristics of the shallow lakes are shown in Tab. 1. The five shallow lakes are eutrophic as to their nutrient concentrations. Nevertheless, most of them exhibited low DIN concentrations (18.6-53 $\left.\mu \mathrm{g}-\mathrm{N} \mathrm{L}^{-1}\right)$. Kakel Huincul showed the lowest TP concentration $\left(20 \mu \mathrm{g} \mathrm{L}^{-1}\right)$, whereas the other clear-vegetated lake, El Triunfo, presented higher values ( $\left.\mathrm{TP}=168 \mu \mathrm{g} \mathrm{L}^{-1}\right)$. The phytoplanktonturbid lakes showed high values of both TP and DIN, whereas the inorganic-turbid lake Yalca presented the
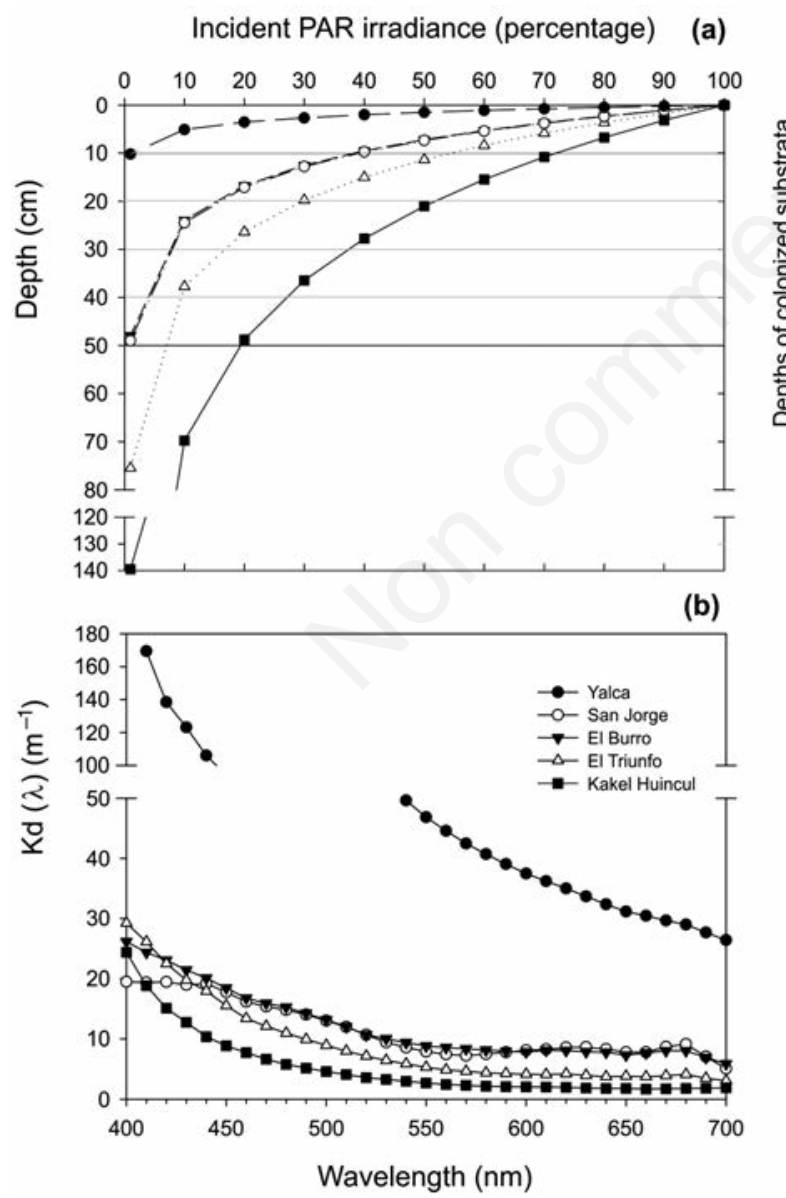

Fig. 2. a) Percentage of incident irradiance at different layers throughout the water columns of the lakes. Irradiance of San Jorge and El Burro are overlapped. b) Spectral light attenuation $[\operatorname{Kd}(\lambda)]$. highest values of nutrient concentrations (TP, DIN and SRP). Values of $\mathrm{pH}$ ranged from 7.4 to 9.4, with the lowest value recorded in Kakel Huincul. Conductivity was high (0.69-1.86 $\left.\mathrm{mS} \mathrm{cm}^{-1}\right)$, which is typical of the shallow lakes of this region.

As far as the optical characteristics are concerned, a gradient of turbidity was found in the lakes studied. Differences were found in the clarity of the shallow lakes classified as clear: Kakel Huincul was clearer, $\left(\mathrm{Kd}_{\mathrm{PAR}} 3.3\right.$ $\mathrm{m}^{-1}$; turbidity $\left.1.45 \mathrm{NTU}\right)$, whereas El Triunfo was considerably more turbid $\left(\mathrm{Kd}_{\mathrm{PAR}} 6.1 \mathrm{~m}^{-1}\right.$; turbidity $\left.9.48 \mathrm{NTU}\right)$ (Tab. 1). The phytoplankton-turbid shallow lakes San Jorge and El Burro were similar in their optical features, both showing intermediate turbidity. The most turbid shallow lake was Yalca, with extremely high values of $\mathrm{Kd}_{\mathrm{PAR}}$ and turbidity. This lake presented the highest value of suspended material, mainly inorganic, as it is common for inorganic-turbid shallow lakes. Fig. 2a shows the percentage of incident irradiance at different layers throughout the water columns for the lakes under study. Spectral light attenuation $[\operatorname{Kd}(\lambda)]$ values are shown in Fig. 2b. All the lakes exhibited higher values of spectral $\mathrm{Kd}$ near the blue region of the spectrum. Both San Jorge and El Burro lakes also showed an increase in the attenuation of red light, corresponding to the second absorption peak of Chl $a$ (Fig. 2a).

The clear-vegetated lakes showed high values of CDOM absorption coefficients $\left(\mathrm{a}_{\mathrm{g}}\right)$, as the absorption by particulate matter, i.e. detritus $\left(\mathrm{a}_{\mathrm{d}}\right)$, is also important in $\mathrm{El}$ Triunfo. The phytoplankton-turbid lakes presented higher values of phytoplankton absorption $\left(\mathrm{a}_{\mathrm{ph}}\right)$ and low values of CDOM. In contrast, Yalca showed high absorption coefficients of both detritus and CDOM (Tab. 1).

\section{Periphyton and phytoplankton}

\section{Clear lakes}

Despite being characterised as clear shallow lakes, both Kakel Huincul and El Triunfo differed in their patterns of periphyton pigment concentration (Figs. 3a,b and 4a,b) as well as in the abundance of the principal algal groups (Figs. 5a,b) and the other mass variables (Figs. 6a,b).

Kakel Huincul did not present significant differences in periphytic $\mathrm{Chl} a$ concentration for different depths, varying scarcely between 0.3 and $0.45 \mu \mathrm{g} \mathrm{cm}^{-2}$ (Fig. 3a). On average, accessory pigments were dominated by $\mathrm{Chl} b$, followed by fucox and zeax+lut. Total accessory pigments did not vary significantly in depth, following the same pattern as $\mathrm{Chl} a$. However, although not significant, $\mathrm{Chl} b$ and fucox varied with depth. An increasing trend of fucox concentration and the relative contribution of fucox/Chl $a$ with depth was observed. An opposite pattern was found for $\mathrm{Chl}$ $b$ and the $\mathrm{Chl} b / \mathrm{Chl} a$ ratio (Fig. 4a). Total densities of the main periphyton taxonomic groups were statistically dif- 

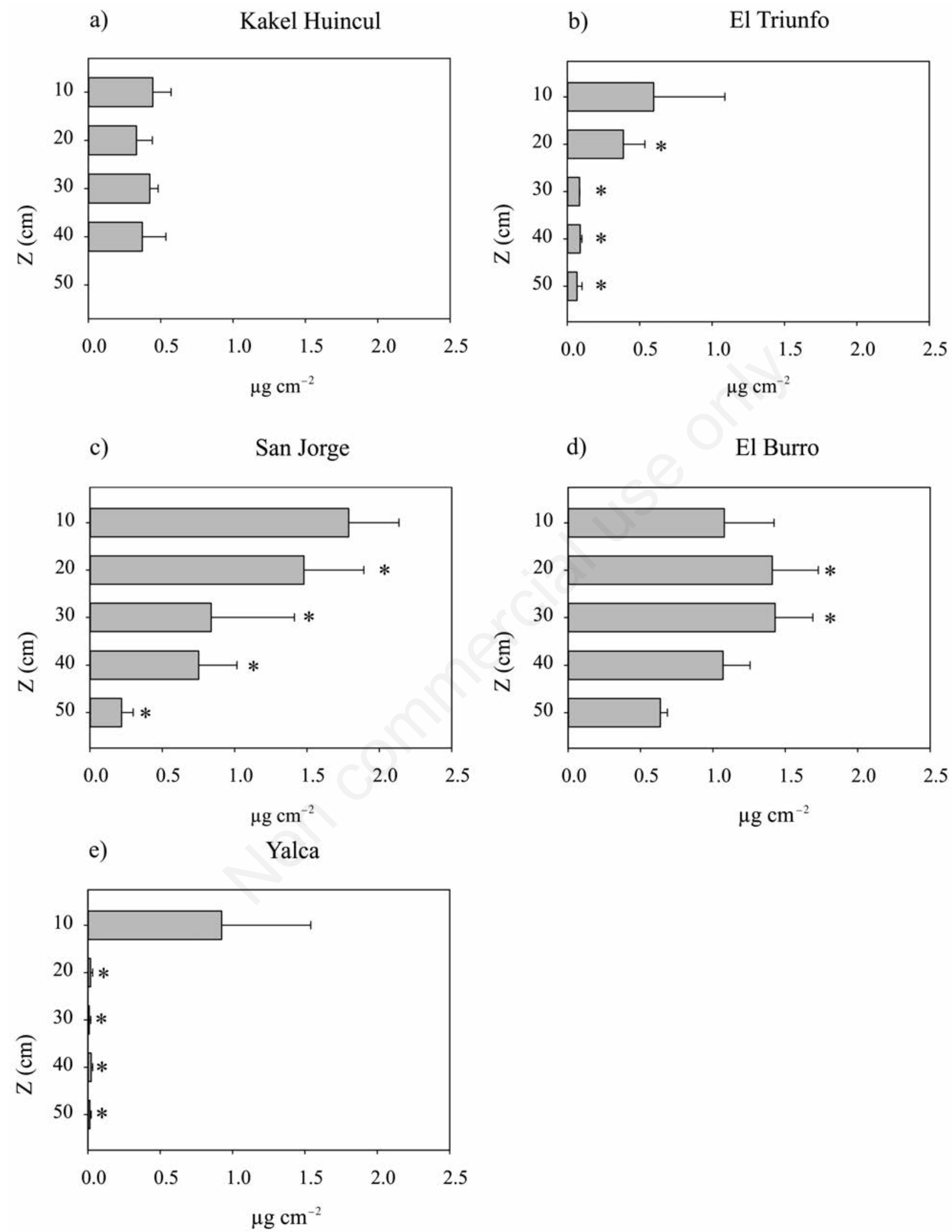

Fig. 3. Periphytic Chl $a$ depth distribution in the shallow lakes $\left({ }^{*} \mathrm{P}<0.05\right)$ : a) Kakel Huincul; b) El Triunfo; c) San Jorge; d) El Burro; e) Yalca. Bars represent \pm SD. 

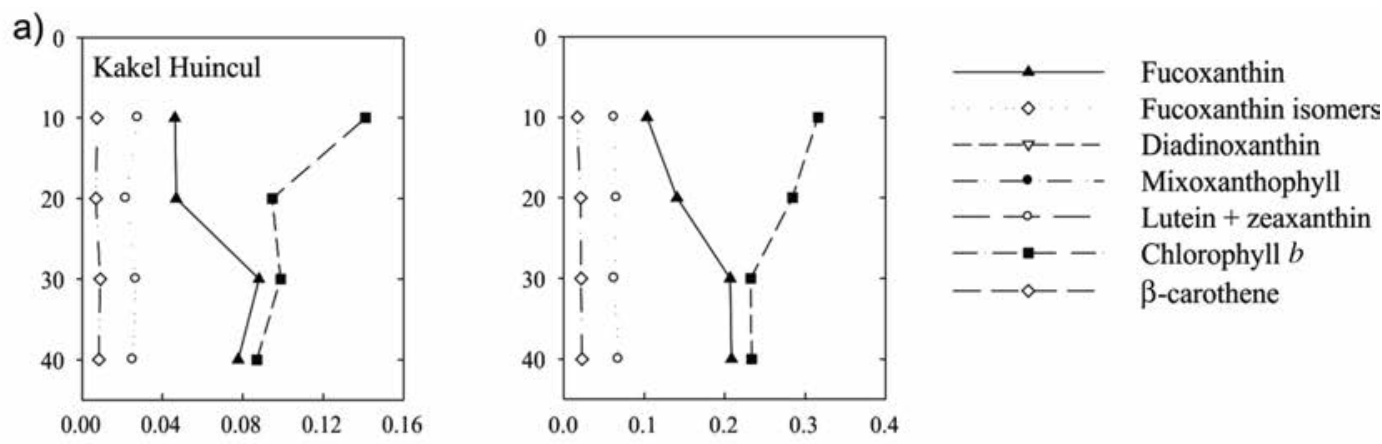

b)
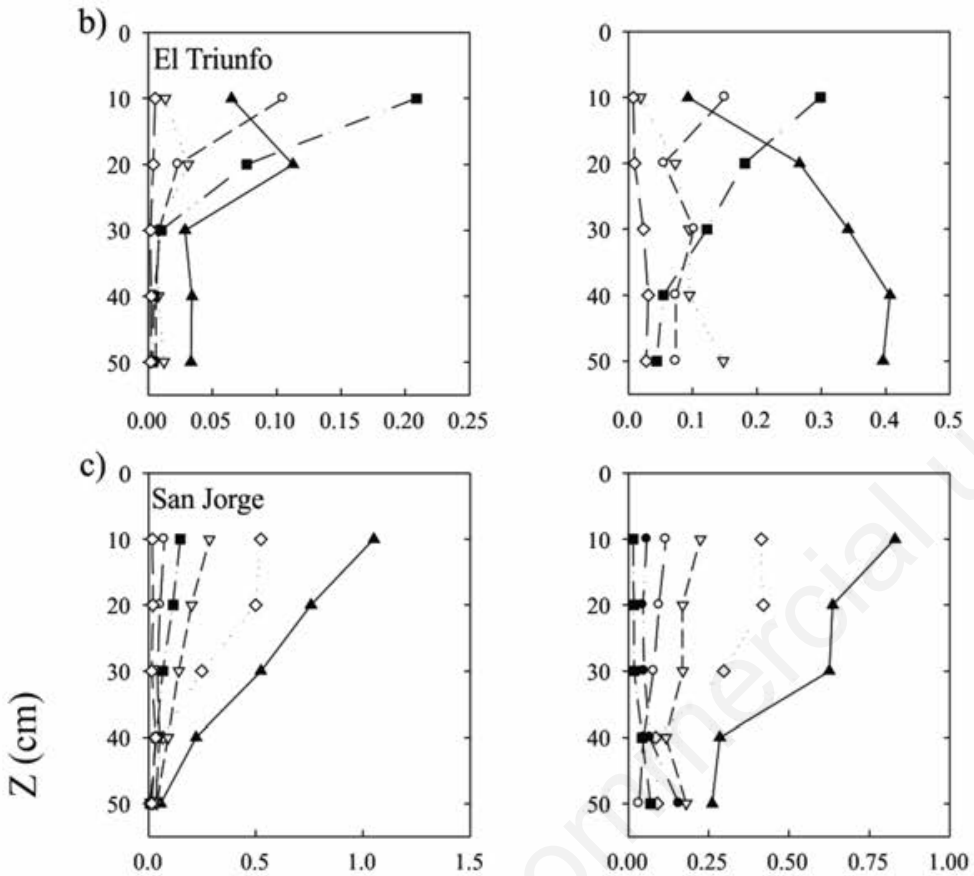

d)
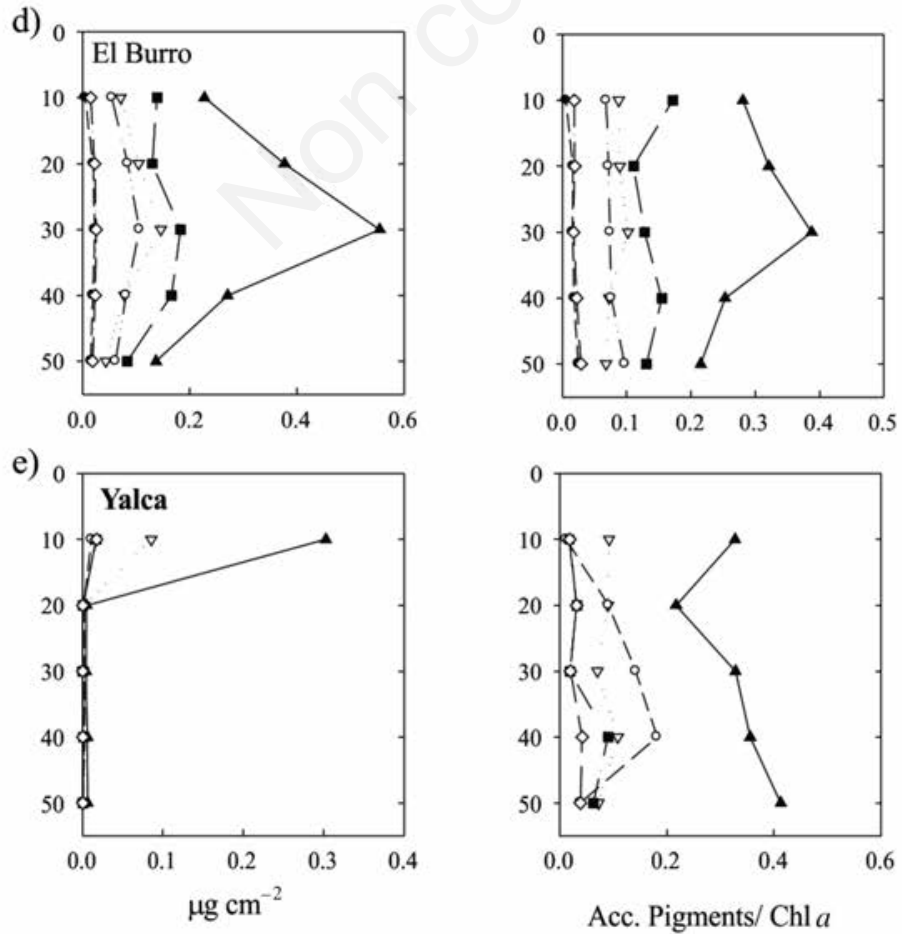

Fig. 4. Chl $a$ relative contribution of the accessory pigments selected (left panels). Mean values of the periphytic accessory pigments selected (as taxonomic markers) throughout depth (right panels). The shallow lakes are presented as follows: a) Kakel Huincul; b) El Triunfo; c) San Jorge; d) El Burro; e) Yalca. Note the differences between the scales of the $\mathrm{X}$-axes. 
ferent in depth $(\mathrm{P}=0.01)$, decreasing after $30 \mathrm{~cm}$ with values ranging between $3.0210^{4}$ ind $\mathrm{cm}^{-2}$ in the first $10 \mathrm{~cm}$ and $1.0510^{4}$ ind $\mathrm{cm}^{-2}$ in depth. Chlorophyta was the main algal group in the upper samples, while at greater depths diatoms were dominant and an increasing importance of Chrysophyceae was also observed (Fig. 5a). No significant differences were detected for DW and AFDW throughout the water column studied. Ash-free dry weight ranged between 13.8 and $142.5 \mu \mathrm{g} \mathrm{cm}^{-2}$, whereas DW between 95.9 $\mu \mathrm{g} \mathrm{cm}^{-2}$ and $151.8 \mu \mathrm{g} \mathrm{cm}^{-2}$. However, AI presented a peak at intermediate depth (Fig. 6a). Phytoplankton ( $>2 \mu \mathrm{m})$ was represented mainly by diatoms, followed by unicellular Chlorophyta. Total phytoplankton density was 263 ind $\mathrm{mL}^{-1}$ (Tab. 2), the lowest value recorded in these shallow lakes. Phytoplankton $\mathrm{Chl} a$ concentration ranged between 3.27 and $1.93 \mu \mathrm{g} \mathrm{L}^{-1}$ (Tab. 1) and the principal accessory pigments were mostly represented by $\mathrm{Chl} b$, zeax+lut, neoxanthin (neox), fucox, and diad (Tab. 2).

On the other hand, El Triunfo presented significant differences in periphytic $\mathrm{Chl} a$ along the water column, with values decreasing from 0.6 to $0.06 \mu \mathrm{g} \mathrm{cm}^{-2}$ $(\mathrm{P}=0.001)$ (Fig. 3b). Total accessory pigments also decreased significantly with depth $(\mathrm{P}=0.001)$, and on average were dominated by $\mathrm{Chl} b$ and fucox, followed by zeax+lut and diad (Fig. 4b). Different trends in pigments/Chl $a$ ratios were observed. Ratios of $\mathrm{Chl} b / \mathrm{Chl} a$ and zeax+lut/Chl $a$ showed a decreasing pattern with depth, while an opposite trend was observed for those of fucox/Chl $a$ and diad/Chl $a$ (Fig. 4b). Total periphyton algal densities ranged from $1.8510^{5}$ ind $\mathrm{cm}^{-2}$ in the first $10 \mathrm{~cm}$ to $3.4810^{3}$ ind $\mathrm{cm}^{-2}$ in the last $50 \mathrm{~cm}$. The upper $20 \mathrm{~cm}$ were dominated by diatoms, followed by Chlorophyta and Cyanobacteria. On the contrary, at greater depths all taxonomic groups decreased $(\mathrm{P}=0.002)$, though the community was still dominated by diatoms (Fig. 5 b). Dry weight and AFDW decreased at $40 \mathrm{~cm}(\mathrm{P}=0.02$ and $\mathrm{P}=0.017$, respectively). Ash-free dry weight maximum value was $212.1 \mu \mathrm{g} \mathrm{cm}^{-2}$ in the first $10 \mathrm{~cm}$ and its minimum value was $65.1 \mu \mathrm{g} \mathrm{cm}^{-2}$ at $50 \mathrm{~cm}$. Dry weight ranged between $53.8 \mu \mathrm{g} \mathrm{cm}^{-2}$ and $254.3 \mu \mathrm{g} \mathrm{cm}^{-2}$. Autotrophic index did not vary with depth (Fig. 6b). In this lake, phy-

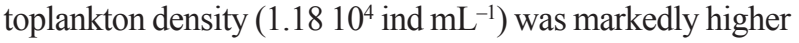
than in the other clear shallow lake (Kakel Huincul), with a co-dominance of Cyanobacteria and Chlorophyta, followed by diatoms (Tab. 2). Phytoplanktonic Chl $a$ was $21.07 \mu \mathrm{g} \mathrm{L}^{-1}$ (Tab. 1) and accessory pigments were represented by Chl $b$, followed by zeax+lut, fucox and myxolike carotenoid (Tab. 2).

\section{Phytoplankton-turbid lakes}

San Jorge and El Burro exhibited similar patterns of the periphyton variables along the vertical profile. Periphytic $\mathrm{Chl} a$ in San Jorge significantly decreased ( $\mathrm{P}=0.003)$ with depth, with values ranging from $1.8 \mu \mathrm{g} \mathrm{cm}^{-2}$ at $10 \mathrm{~cm}$ to
$0.2 \mu \mathrm{g} \mathrm{cm}^{-2}$ at $50 \mathrm{~cm}$ (Fig. 3c). In accordance with $\mathrm{Chl} a$, total selected accessory pigments also decreased with depth $(\mathrm{P}=0.009)$. On average, fucox was the principal accessory pigment, followed by the fucox isomer, diad and Chl $b$ (Fig. 4c). Accessory pigments/Chl $a$ ratios mostly showed a decreasing pattern with increasing depth, while zeax + lut $/ \mathrm{Chl} a$ and $\beta$-carot/Chl $a$ depicted an opposite trend. Total periphyton densities decreased below $20 \mathrm{~cm}$ $(\mathrm{P}=0.002)$. In surface waters, diatoms were dominant, whereas at deeper samples the community shifted to be dominated by Cyanobacteria (Fig. 5c), especially by those with the filamentous habit. Dry weight and AFDW did not vary with depth: DW ranged between $2196.8 \mu \mathrm{g} \mathrm{cm}^{-2}$ and $3918.4 \mu \mathrm{g} \mathrm{cm}^{-2}$, while AFDW between $812.9 \mu \mathrm{g} \mathrm{cm}^{-2}$ and $1121.5 \mu \mathrm{g} \mathrm{cm}^{-2}$. Autotrophic index increased $(\mathrm{P}=0.003)$ with depth, contributing to an increase in the heterotrophic characteristics of this community (Fig. 6c).

In the San Jorge phytoplankton community, the total algal density was around $2.1510^{5} \mathrm{ind} \mathrm{mL}^{-1}$, with dominance of filamentous Cyanobacteria (98\%) (almost exclusively Planktothrix aghardii and Raphidiopsis mediterranea) (Tab. 2). Phytoplanktonic $\mathrm{Chl} a$ was the highest planktonic $\mathrm{Chl} a$ (207.64 $\mu \mathrm{g} \mathrm{L}^{-1}$ ) recorded amongst these lakes (Tab. 1). A nonidentified carotenoid (carot 16.54) dominated the accessory pigments, followed by $\beta$-carot, zeax+lut and myxo (Tab. 2).

As for periphytic Chl $a$ in El Burro, values ranged between 1.4 and $0.6 \mu \mathrm{g} \mathrm{cm}^{-2}$. They significantly increased between 10 and $30 \mathrm{~cm}(\mathrm{P}=0.02)$ and decreased from 30 to 50 cm $(\mathrm{P}=0.003)$ (Fig. $3 \mathrm{~d})$. The accessory pigments generally showed the same general pattern as Chl $a$ (Fig. 4d). On average, accessory pigments were dominated by fucox, followed by $\mathrm{Chl} b$, diad and zeax+lut. Accessory pigments/Chl $a$ ratios, in general, slightly varied with depth, though fucox/Chl $a$ showed a maximum value at $30 \mathrm{~cm}$ (Fig. 4d). Periphytic total densities decreased with depth $(\mathrm{P}=0.0003)$, ranging from $1.9510^{5}$ to $2.9710^{4}$ ind $\mathrm{cm}^{-2}$. Along the profile, diatoms were dominant, followed by Chlorophyta and Cyanobacteria (Fig. 5d). Ash-free dry weight did not vary with depth (463.1 $\mu \mathrm{g} \mathrm{cm}^{-2}$ on average), while DW and ash increased ( $\mathrm{P}=0.01$ and $\mathrm{P}=0.0008$, respectively). Dry weight values increased from $380.9 \mu \mathrm{g} \mathrm{cm}^{-2}$ to $1235.7 \mu \mathrm{g} \mathrm{cm}^{-2}$. Autotrophic index too showed a tendency to increase, still this was not statistically significant (Fig. 6d). In El Burro phytoplankton was dominated by Chlorophyta - represented by desmids -, unicellular Chlorophyta, and some species of Scenedesmus, followed in smaller proportion by diatoms and Cyanobacteria (Tab. 2). Total density was almost 5.6 $10^{4}$ ind $\mathrm{mL}^{-1}$ (Tab. 2) with a Chl $a$ concentration of 93.06 $\mu \mathrm{g} \mathrm{L}^{-1}$ (Tab. 1). The principal accessory pigments were represented by zeax+lut, followed by myxo and $\mathrm{Chl} b$ (Tab. 2).

\section{Inorganic-turbid lake}

In Yalca, periphytic Chl $a$ markedly decreased in one order of magnitude from $0.9 \mu \mathrm{g} \mathrm{cm}^{-2}$ in the first $10 \mathrm{~cm}$ to 
a)

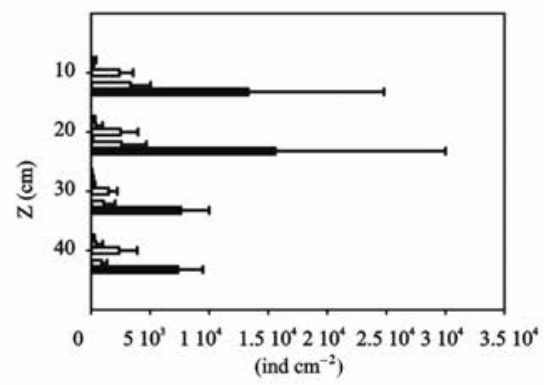

Diatoms

Chloropyhta

E.:영 Euglenophyta

Cyanobacteria

$\because \because$ Chrysophyceae

戸 Xantophyceae

Cryptophyta

b)
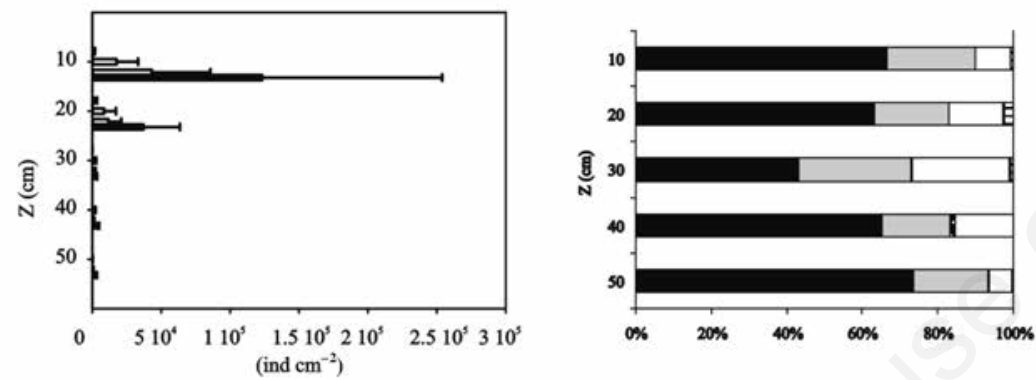

c)

San Jorge
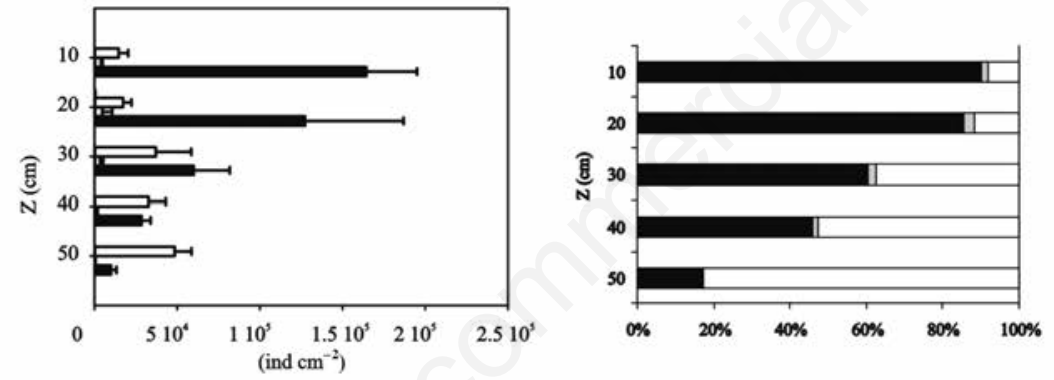

d)

El Burro
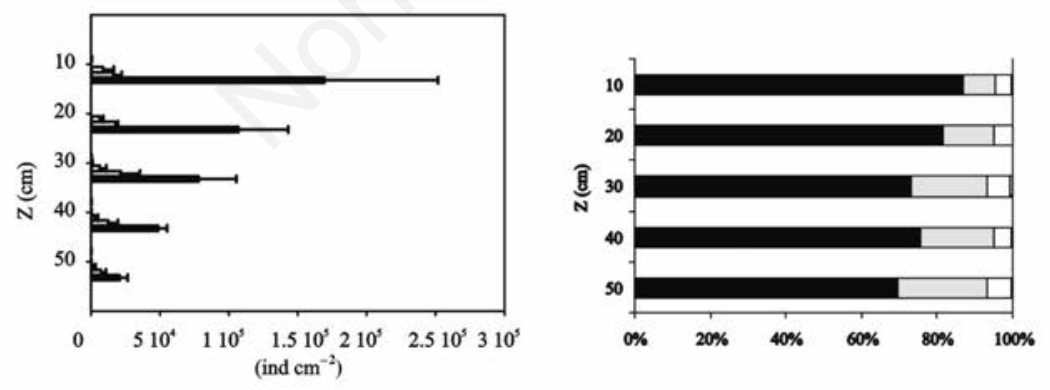

e)
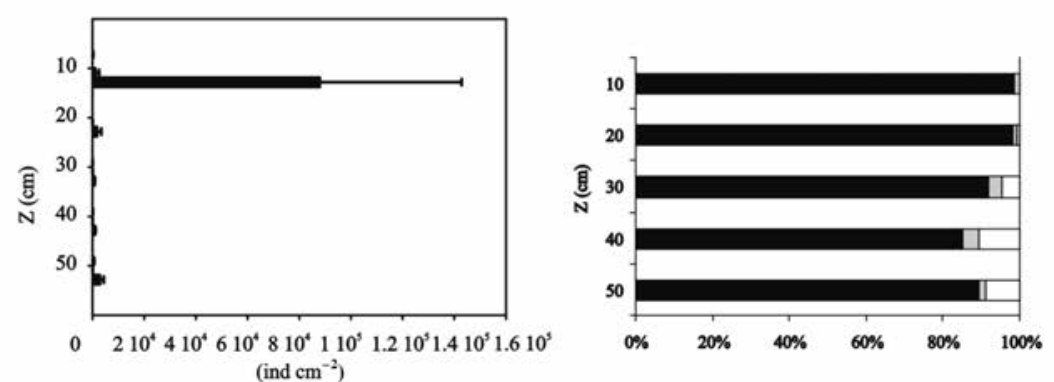

Fig. 5. Density (left panels) and relative contribution (right panels) of the principal taxonomic groups in periphyton community in the five shallow lakes studied. The shallow lakes are presented as follows: a) Kakel Huincul; b) El Triunfo; c) San Jorge; d) El Burro; e) Yalca. Note the differences between the scales of the $\mathrm{X}$-axes in density graphs. Bars represent \pm SD. 
$0.02 \mu \mathrm{g} \mathrm{cm}^{-2}$ at $20 \mathrm{~cm}(\mathrm{P}=0.00059)$. Afterwards, it continued to show low values (Fig. 3e). The accessory pigments showed the same trend as $\mathrm{Chl} a$, and on average were principally composed of fucox, followed by diad and $\mathrm{Chl} b$. (Fig. 4e). With depth, the relative concentration of accessory pigments was almost similar to that of $\mathrm{Chl} a$, while fucox/Chl $a$ increased from 20 to $50 \mathrm{~cm}$ and zeax+lut/Chl $a$ from 10 to $40 \mathrm{~cm}$. Total periphyton algal density sharply decreased below the first $10 \mathrm{~cm}$ from 8.91 $10^{4}$ ind $\mathrm{cm}^{-2}$ to $3.2010^{3}$ ind $\mathrm{cm}^{-2}(\mathrm{P}=0.00004)$. Diatoms dominated the first $10 \mathrm{~cm}$, while the relative contribution of Cyanobacteria increased onward (Fig. 5e). Ash-free dry weight significantly diminished $(\mathrm{P}=0.0006)$ from 131.3 $\mu \mathrm{g} \mathrm{cm}^{-2}$ at $10 \mathrm{~cm}$ to $71.1 \mu \mathrm{g} \mathrm{cm}^{-2}$ at $20 \mathrm{~cm}$, whereas DW values ranged from $418.2 \mu \mathrm{g} \mathrm{cm}^{-2}$ in the upper samples to $47.5 \mu \mathrm{g} \mathrm{cm}^{-2}$ in depth. Autotrophic index increased with depth $(\mathrm{P}=0.03)$, thus showing a tendency towards the heterotrophic community (Fig. 6e). Phytoplankton total density in Yalca was 110 ind $\mathrm{mL}^{-1}$ and was dominated by diatoms, followed by Chlorophyta (Tab. 2). Phytoplanktonic Chl $a$ was $11.14 \mu \mathrm{g} \mathrm{L}^{-1}$ (Tab. 1) and the principal accessory pigments were mostly represented by zeax+lut, followed by $\mathrm{Chl} b$ and fucox (Tab. 2).

The comparison of the concentrations of Chl $a$ and the total accessory pigments of both microalgal communities is illustrated in Fig. 7. Phytoplankton had a higher pigment concentration in the phytoplankton-turbid lake San Jorge, whereas periphyton showed higher concentrations in the clear lake Kakel Huincul. The shallow lakes El Burro and Yalca exhibited higher pigment concentrations of phytoplankton than of periphyton, though the differences were smaller than for the other lakes (Fig. 7).

\section{DISCUSSION}

Our results showed that the differences in optical features and nutrient concentration across the shallow lakes were reflected in the algal and pigment composition of their periphyton and phytoplankton. Precisely, periphyton showed different degrees of development according to the combination of nutrients and light that occur in the three lake categories described in this region (Quirós et al., 2002; Allende et al., 2009). This finding supports our first hypothesis. Moreover, the periphyton structure changed along the water column according to different light penetrations, both in quantity and spectral composition. This finding supports our second hypothesis.

Although different factors (e.g., grazing) may influence the composition and biomass of the autotrophic microbial communities, previous studies on the shallow lakes of this region showed that light and nutrients are the key factors (Torremorell et al., 2007; Allende et al., 2009; Llames et al., 2009; Pérez et al., 2010). Importantly, even though our study was conducted during a particular season (late spring), in these shallow lakes the underwater

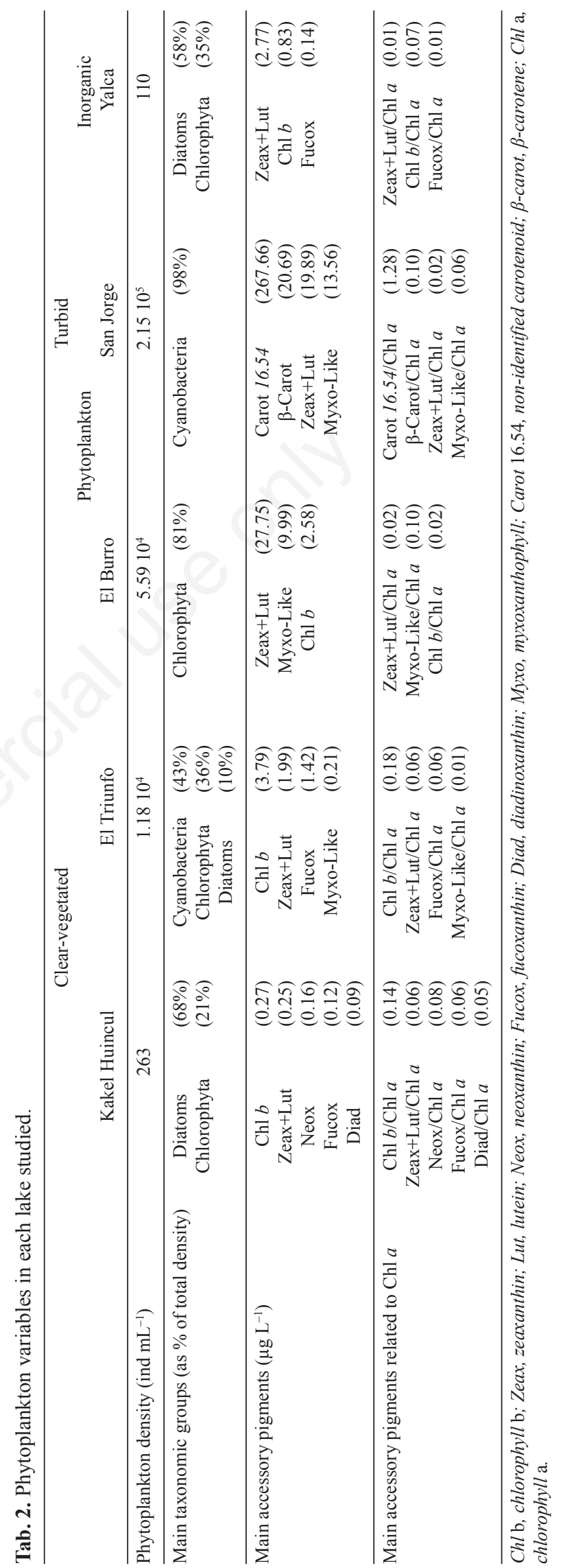


a)

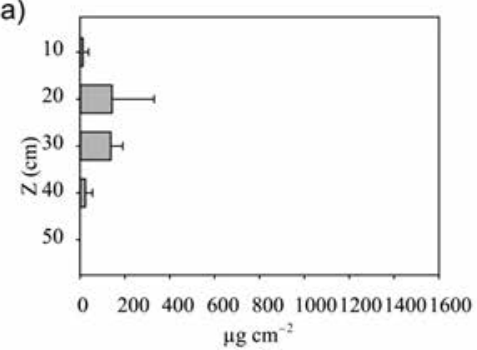

b)

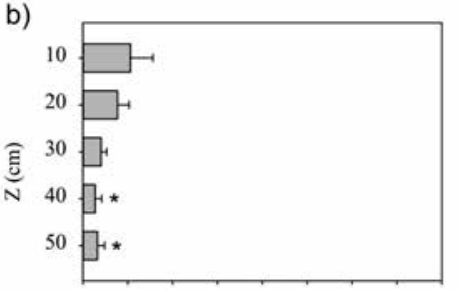

$\begin{array}{llllll}0 & 200 & 400 & 600 & 800 & 1000120014001600\end{array}$ $\mu \mathrm{g} \mathrm{cm}^{-2}$

c)

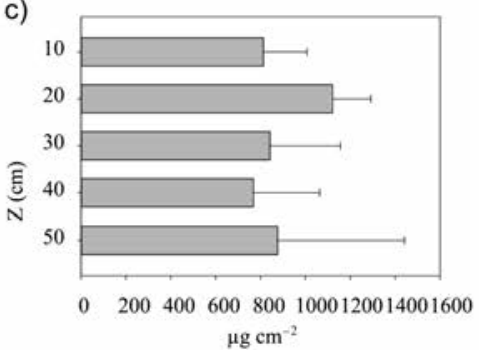

d)

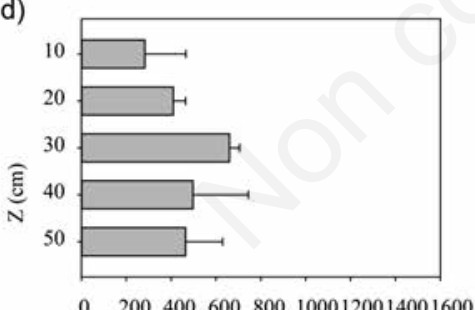

$\mu \mathrm{g} \mathrm{cm}^{-2}$

e)

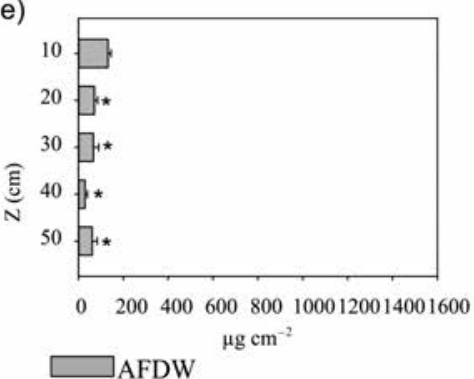

Kakel Huincul
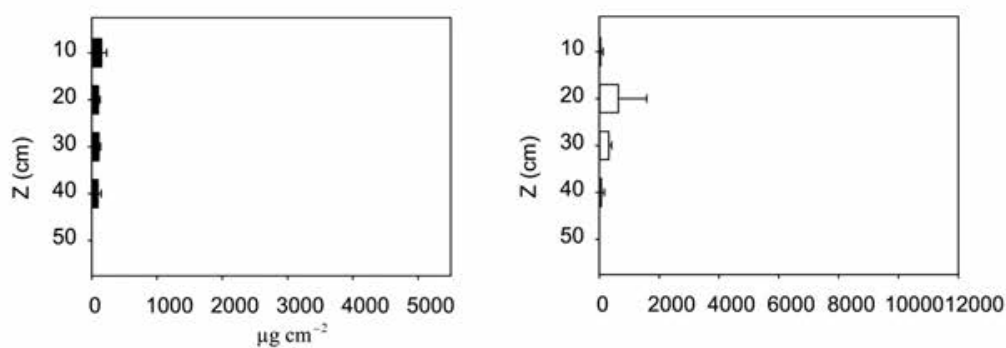

El Triunfo
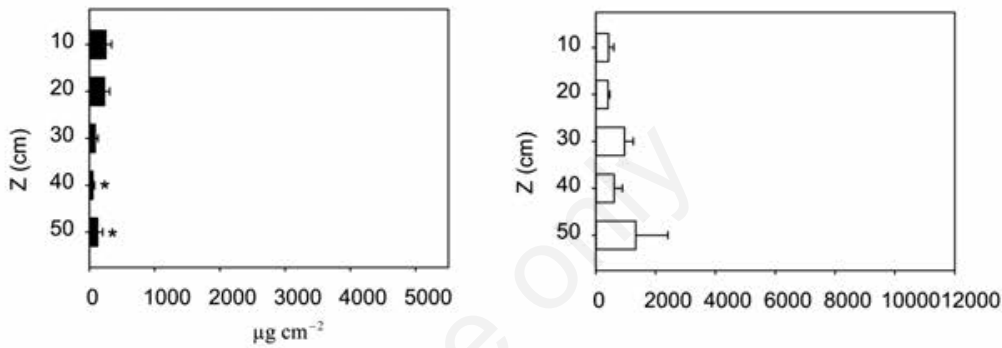

San Jorge
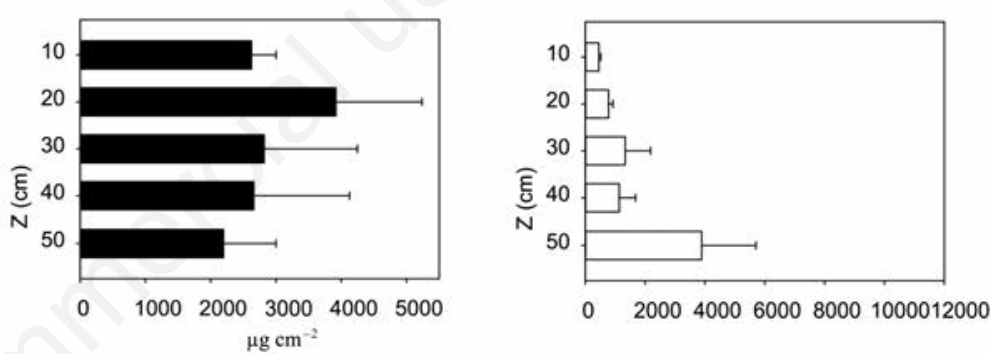

El Burro
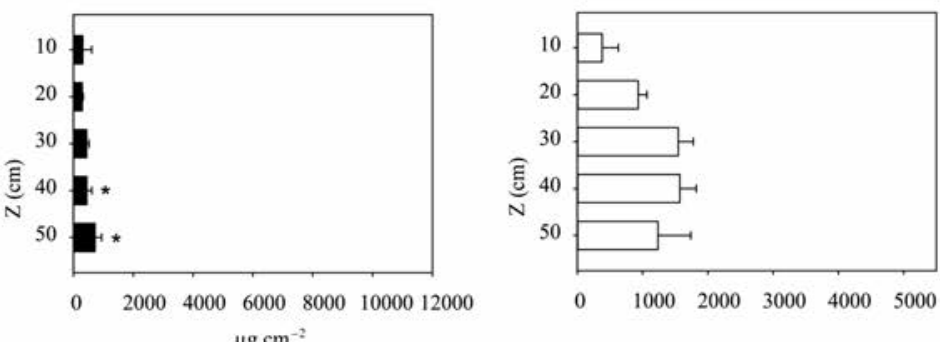

Yalca

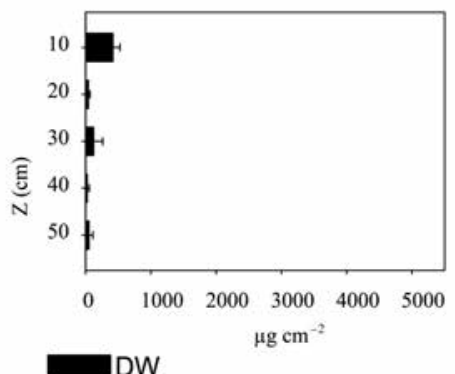

Fig. 6. Ash-free dry weight (AFDW), dry weight (DW) and autotrophic index (AI) in the shallow lakes studied (*P<0.05): a) Kakel Huincul; b) El Triunfo; c) San Jorge; d) El Burro; e) Yalca. Bars represent \pm SD. 
light and nutrient conditions remain rather constant over the year, as reported in previous studies (Allende et al., 2009; Pérez et al., 2010; Silvoso et al., 2011; Izaguirre et al., 2012).

Regardless of the nutrient concentration of each lake, we observed a general decreasing pattern in the mean values of periphytic density with depth, following a reduction of light availability along the water column. In addition, we found a depth stratification in the attached algal assemblages, which was generally consistent with the vertical profiles of the accessory pigments analysed. In clear lakes, near-surface periphytic communities were co-dominated by chlorophytes and diatoms in terms of density. At deeper samples, diatoms were dominant. This outcome may be explained by the fact that diatoms better adapt to growth under low light intensities than Chlorophyta (Hill 1996;
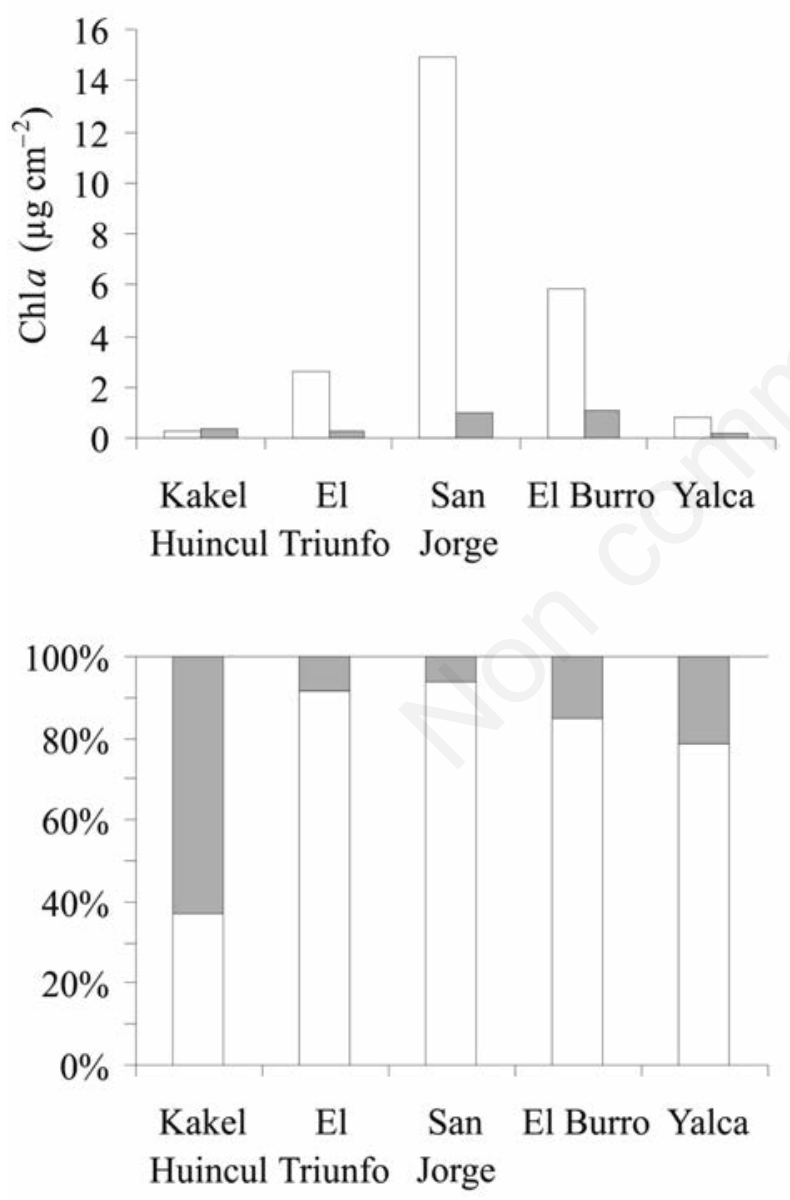

\section{$\square$ Phytoplankton $\square$ Periphyton}

Fig. 7. Chl $a$ concentrations in periphyton and phytoplankton in the five shallow lakes studied. Concentrations in both communities are expressed as $\mathrm{mg} \mathrm{cm}^{-2}$ (above), and as percentage (below) and are referred to the area.
Huisman et al., 1999). In particular, in Kakel Huincul, the decrease in diatom abundance with depth was not followed by a decrease in fucox concentration, which could indicate a photoacclimation of deep diatom assemblages. Changes in light-harvesting pigment concentrations due to photoacclimation processes have been previously observed in benthic diatoms (Laviale et al., 2009).

In turbid lakes (phytoplankton- and inorganic-), the surface assemblages of periphyton were mainly dominated by diatoms. In San Jorge (phytoplankton-turbid) and Yalca (inorganic-turbid), the relative contribution of Cyanobacteria increased with depth, becoming dominant in San Jorge. This vertical distribution is not the common pattern observed since diatoms usually dominate deep strata and Cyanobacteria abound in surface zones (Hawes and Smith, 1994; Rouf et al., 2010). However, Cyanobacteria have been cited as a group well adapted to low light and environmental conditions characteristic of turbid eutrophic waters (Tilzer, 1987; Scheffer et al., 1997). Cyanobacteria can effectively harvest orange-red light because of their unique pigment - phycocyanin - which has maximum absorbance at around $630 \mathrm{~nm}$ (Stomp et al., 2004). Therefore, the chromatic adaptation of Cyanobacteria could yield a competitive advantage in turbid water columns with a rapid decrease in blue light and higher availability of orange-red light, a spectral composition retrieved in Yalca. In addition, the increasing trend in depth of fucox/Chl $a$ rate indicates an increase of fucox intracellular concentration due to an acclimation of diatoms to decreasing light intensity.

On the other hand, the dominance of Cyanobacteria in deeper periphytic samples of San Jorge would be attributable to the contribution of phytoplanktonic Cyanobacteria in the periphytic matrix. As a matter of fact, filamentous Cyanobacteria almost exclusively composed the phytoplankton community. The incorporation of some planktonic organisms in the periphyton is common in mixed shallow lakes (Brown and Austin 1973; Sánchez et al., 2010) and frequently observed in deep periphytic assemblages (Stevenson and Stoermer, 1981). It is important to point out that, despite sharing some species, both communities are still distinguishable in these water bodies. The criterion for the discrimination between strictly periphytic and phytoplanktonic taxa was based on the presence of fixation structures in the first ones, and on the description of the common habitats for each species according to the literature (Komárek and Fott, 1983; Krammer and Lange-Bertalot, 1986, 1988, 1991a, 1991b; Vinocur et al., 1994; Komárek and Anagnostidis, 1999, 2005).

We observed lower periphyton accrual (as Chl $a$ and algal density) in Kakel Huincul and Yalca - shallow lakes presenting boundary values in the restrictions of either nutrients or light. In the clearer lake Kakel Huincul, light penetrates more deeply, being mainly absorbed by CDOM. 
Therefore, light availability does not seem to be a limiting factor for the development of microalgae (both phytoplankton and periphyton). This fact is reflected in similar periphyton abundances and pigment concentrations along the depth profile. Besides, we observed a prevalence of the autotrophic fraction in periphyton composition (lower values of AI). Instead, in this lake, the resource limiting algal development seems to be nutrient availability (in particular nitrogen). In this scenario, periphyton and phytoplankton may compete strictly for nutrients. Eminson and Moss (1980) indicated that periphyton is well adapted to uptake nutrients from the water column at low concentrations and to have low growth rates adjusted to the rate of nutrient supply. Thus, it emerges as a good competitor in such environmental conditions. The responses of the microalgal communities in Kakel Huincul showed that periphyton was better adapted than phytoplankton, which presented the lowest Chl $a$ concentration $\left(<2 \mu \mathrm{gL}^{-1}\right)$ in this study. However, the strong nutrient limitation probably caused a restricted development of the periphyton community along the depth profile (i.e. low periphytic accrual) in comparison with the other shallow lakes.

On the other hand, the inorganic-turbid lake Yalca is characterised by a strong light limitation. Indeed, the large amount of suspended inorganic particles in the water causes high light absorption and scattering. In this lake, periphyton developed mainly in the upper samples (10 $\mathrm{cm}$ ), where light was about $1 \%$ of incident PAR irradiance, even when plentiful nutrient concentration was available. Below $10 \mathrm{~cm}$ depth, periphyton development was limited by light which dramatically diminished the autotrophic fraction, being dominant the heterotrophic components. This was evidenced from the high values of the AI according to the reference values reported in APHA (2005). In this scenario of extreme light limitation, diatoms were dominant both in periphyton and phytoplankton communities. Even though phytoplankton was poorly developed in Yalca with respect to the phytoplankton-turbid lakes studied (i.e. San Jorge and El Burro), the relative contribution of this community was higher than that of periphyton. Phytoplankton probably has an advantage for light because water mixing allows algae to reach well-lit surface layers (Vadeboncoeur and Steinman, 2002).

Nutrient limitation was also evidenced in the other clear-vegetated shallow lake (El Triunfo). An increase in TP concentration elicited a near-surface significant increase in periphyton density (between 6 and 3 fold) as compared to that observed in Kakel Huincul. However, periphyton accrual showed a rapid decrease below $20 \mathrm{~cm}$, where light availability was lower than that estimated at deeper layers of Kakel Huincul. The particular pattern of periphyton distribution along depth in this lake suggests a simultaneous limitation of nutrient and light. In El Triunfo, the euphotic zone was about half narrower than that of Kakel Huincul due to i) higher absorption and scattering by suspended particles (phytoplankton and detritus) and ii) higher absorption by CDOM. However, in the upper layers, the combination of enough light and nutrient availability allowed high periphyton development. With increasing depth and light limitation, nutrients seemed not to be sufficient to stimulate periphyton growth. In natural conditions, a shading effect of the macrophytes could occur in El Triunfo since extensive areas of the water column were covered by a nonrooted macrophyte (Ceratophyllum sp.) which occasionally could cover the artificial substrata (personal observations). In spite of a relatively less clear condition, El Triunfo showed characteristics typical of a clear-vegetated shallow lake, as already described by Scheffer et al. (1993). The increase in the relative importance of phytoplankton in this lake seems to reveal the oscillations of the system within the clear stable state.

In the phytoplankton-turbid lakes San Jorge and El Burro, both periphyton and phytoplankton communities showed a higher development, favoured by high nutrient concentrations and a well-mixed water column. These lakes were very similar in their optical properties. An important fraction of light absorption and scattering is due to chlorophyllous particles, which are the main contributors in San Jorge (Pérez et al., 2010). Both water bodies exhibited high values of light attenuation and turbidity, which elicited a strong light gradient. Interestingly, in this scenario rich in nutrients but restricted in light, periphyton developed even at deep layers, but it was dominated by the heterotrophic fraction from $20 \mathrm{~cm}$ towards the bottom. This was demonstrated by the higher AI values recorded. In these turbid lakes, where the light availability was $\sim 5 \%$ of the incident irradiance at $40 \mathrm{~cm}$, the presence of autotrophic organisms could indicate a community well acclimated to low light conditions. Nevertheless, under these conditions the phytoplankton was the dominant microbial autotrophic community. Moreover, if we consider the lack or sparse presence of macrophytes in these shallow lakes, only shallow littoral zones may allow the development of epipelon communities.

We observed an increase in the relative importance of phytoplankton with respect to periphyton with decreasing light availability, and increasing turbidity and nutrient concentration. These patterns considered, we can infer that phytoplankton develops more than periphyton with increasing eutrophication, in agreement with previous reports (Liboriussen and Jeppesen, 2006; Vadeboncoeur et al., 2008).

The pigment composition - matched with the community species composition - evidenced the strategies of the different groups to adapt to different light availability. When comparing pigment concentration, we found important differences between both microalgal communities. Periphyton is a sessile community which exhibited a marked 
stratification in the dominant group and pigment concentrations depending on the optical characteristic of the lake and the depth studied. Moreover, we found a trend to heterotrophism in accordance with the increase in turbidity. On the other hand, different algal groups were observed to dominate phytoplankton and periphyton at a given category of shallow lake. This may be explained by the polymictic regime of these water bodies, which allowed phytoplankton to exploit a higher proportion of the water profile.

\section{CONCLUSIONS}

Our results showed that the importance of the autotrophic periphyton decreases in shallow lakes with higher nutrient conditions and low light availability. The optical regime of the water bodies influenced the pigment composition of both periphyton and phytoplankton communities. Under limiting conditions we found an increase of some accessory pigments in relation to $\mathrm{Chl} a$, indicating light acclimation. In turbid lakes the structure of the periphytic community changed in the water column from autotrophic to heterotrophic towards the bottom.

\section{ACKNOWLEDGMENTS}

The authors are grateful to the owners of the farms where the lakes are located for allowing us to have access to the water bodies studied.

They also thank the members of the Laboratorio de Ecología y Fotobiología Acuática from IIB-INTECH (Chascomús) and the Laboratorio de Limnología (UBA) for the field assistance and Lic. Leonardo Lagomarsino for the nutrient analysis. The two anonymous reviewers who improved the manuscript with their comments are gratefully acknowledged.

This research was supported by a grant of the University of Buenos Aires (UBACyT X838) and by ANPCyT (PICT07-429-9).

\section{REFERENCES}

Allende L, Tell G, Zagarese H, Torremorell A, Pérez G, Bustingorry J, Escaray R, Izaguirre I, 2009. Phytoplankton and primary production in clear-vegetated, inorganic-turbid and algal turbid shallow lakes from the pampa plain (Argentina). Hydrobiologia 624:45-60.

APHA, 2005. Standard methods for the examination of water and waste waters. American Public Health Association ed., Washington DC: $1217 \mathrm{pp}$.

Belmont P, Hargreaves BR, Morris DP, Williamson CE, 2007. Estimating attenuation of ultraviolet radiation in streams: field and laboratory methods. Photochem Photobiol 83:1339-1347.

Bricaud A, Stramski D, 1990. Spectral absorption of living phytoplankton and nonalgal biogenus matter: A comparison between the Peru upwelling area and the Sargasso Sea. Limnol. Oceanogr. 35:562-582.

Brown SD, Austin AP, 1973. Diatom succession and interaction in littoral periphyton and plankton. Hydrobiologia 43:333356.

Cano MG, Casco MA, Solari LC, Mac Donagh ME, Gabellone NA, Claps MC, 2008. Implications of rapid changes in chlorophyll-a of plankton, epipelon and epiphyton in a Pampean shallow lake: an interpretation in terms of a conceptual model. Hydrobiologia 614:33-45.

Casco MA, Mac Donagh ME, Cano MG, Solari LC, Claps MC, Gabellone NA, 2009. Phytoplankton and epipelon responses to clear and turbid phases in a seepage lake (Buenos Aires, Argentina). Int. Rev. Hydrobiol. 94:153-168.

Cleveland JS, Weidemann AD, 1993. Quantifying absorption by particles: a multiple scattering correction for glass-fiber filters. Limnol. Oceanogr. 38:1321-1327.

Eminson D, Moss B, 1980. The composition and ecology of periphyton communities in freshwaters. Eur. J. Phycol. 15:429-446.

Falkowski PG, LaRoche J, 1991. Acclimation to spectral irradiance in algae. J. Phycol. 27:8-14.

Falkowski PG, Raven JA, 2007. Aquatic photosynthesis, $2^{\text {nd }}$ ed. Princeton University Press: 484 pp.

Goldsborough LG, Robinson GGC, 1996. Pattern in wetlands, p. 77-117. In: R.J. Stevenson, M.L. Bothwell, R.L. Lowe (eds.), Algal ecology: freshwater benthic ecosystems. Academic Press, San Diego.

Hansson LA, 1988. Effects of competitive interactions on the biomass development of planktonic and periphytic algae in lakes. Limnol. Oceanogr. 33:121-128.

Hawes I, Smith R, 1994. Seasonal dynamics of epilithic periphyton in oligotrophic Lake Taupo, New Zealand. New Zeal. J. Mar. Fresh. 28:1-12.

Hill W, 1996. Effects of light, p. 121-148. In: R.J. Stevenson, M.L. Bothwell, R.L. Lowe (eds.), Algal ecology: freshwater benthic ecosystems. Academic Press, San Diego.

Huisman J, Jonker RR, Zonneveld C, Weissing FJ, 1999. Competition for light between phytoplankton species: experimental test of mechanistic theory. Ecology 80:211-222.

Hurley JP, 1988. Analysis of aquatic pigments by high performance liquid chromatography. J. Anal. Purif. 3:12-16.

Izaguirre I, Allende L, Escaray R, Bustingorry J, Pérez G, Tell G, 2012. Comparison of morpho-functional phytoplankton classifications in human-impacted shallow lakes with different stable states. Hydrobiologia 698:203-216.

Izaguirre I, Vinocur A, 1994a. Typology of shallow lakes of the Salado River basin (Argentina), based on phytoplankton communities. Hydrobiologia 277:49-62.

Izaguirre I, Vinocur A, 1994b. Algal assemblages from shallow lakes of the Salado River basin (Argentina). Hydrobiologia 289:57-64.

Kalff J, 2003. Limnology: inland waters ecosystems. PrenticeHall, New Jersey, 592 pp.

Kirk JTO, 1994. Light and photosynthesis in aquatic ecosystems, $2^{\text {nd }}$ ed. Cambridge University Press: 509 pp.

Kishino M, Takahashi M, Okami N, 1985. Estimation of the spectral absorption coefficients of phytoplankton in the sea. B. Mar. Sci. 37:634-642.

Komárek J, Anagnostidis K, 1999. [Cyanoprokaryota, 1. Teil: Chroococcales]. In: H. Ettl, G. Gärtner, H. Heynig, D. Mollenhauer (eds.), [Süßwasserflora von Mitteleuropa 19/1]. [Book in German]. Gustav Fischer Verlag, Stuttgart: 548 pp. Komárek J, Anagnostidis K, 2005. [Cyanoprokaryota, 2. Teil: 
Oscillatoriales]. In: B. Büdel, G. Gärtner, L. Krienitz, M. Schagerl (eds.), [Süßwasserflora von Mitteleuropa 19/2]. [Book in German]. Elsevier, Spectrum Akamedischer Verlag, München: 759 pp.

Komárek J, Fott B, 1983. [Chlorophyceae (Grünalgen), Ordnung: Chlorococcales]. In: G. Huber-Pestalozzi, H. Heynig, D. Mollenhauer (eds.), [Das Phytoplankton des Süsswassers, Die Binnengewässer. 7 Teil]. [Book in German]. E. Schweizerbart'sche Verlagsbuchhandlung, Stuttgart, 548 pp.

Krammer K, Lange-Bertalot H, 1986. [Bacillariophycea, 1. Naviculaceae]. In: H. Ettl, J. Gerloff, H. Heying, D. Mollenhauer (eds.), [Süßwasserflora von Mitteleuropa 2/1]. [Book in German]. Gustav Ficher Verlag, Jena: 876 pp.

Krammer K, Lange-Bertalot H, 1988. [Bacillariophyceae, 2. Bacillariaceae, Epithemiaceae, Surirellaceae]. In: H. Ettl, J. Gerloff, H. Heying, D. Mollenhauer (eds.), [Süßwasserflora von Mitteleuropa 2/2]. [Book in German]. Gustav Ficher Verlag, Jena: 596 pp.

Krammer K, Lange-Bertalot H, 1991a. [Bacillariophyceae, 3. Centrales, Fragilariaceae, Eunotiaceae]. In: H. Ettl, J. Gerloff, H. Heying, D. Mollenhauer (eds.), [Süßwasserflora von Mitteleuropa 2/3]. [Book in German]. Gustav Ficher Verlag, Jena: 576 pp.

Krammer K, Lange-Bertalot H, 1991b. [Bacillariophyceae, 4. Achnanthaceae, Kritischie Ergänzungen zu Navicula (Lineolate) und Gomphonema]. In: H. Ettl, J. Gerloff, H. Heying, D. Mollenhauer (eds.), [Süßwasserflora von Mitteleuropa 2/4]. [Book in German]. Gustav Ficher Verlag, Jena: 473 pp.

Laurion I, Lami A, Sommaruga R, 2002. Distribution of mycosporine-like amino acids and photoprotective carotenoids among freshwater phytoplankton assemblages. Aquat. Microb. Ecol. 26:283-294.

Laviale M, Prygiel J, Lemoine Y, Courseaux A, Créach A, 2009. Stream periphyton photoacclimation response in field conditions: effect of community development and seasonal changes. J. Phycol. 45:1072-1082.

Liboriussen L, Jeppesen E, 2006. Structure, biomass and depth distribution of periphyton on artificial substratum in shallow lakes with contrasting nutrient concentrations. Freshwater Biol. 51:95-109.

Llames ME, Lagomarsino L, Diovisalvi N, Fermani P, Torremorell AM, Pérez G, Unrein F, Bustingorry J, Escaray R, Ferraro M, Zagarese H, 2009. The effects of light availability in shallow, turbid waters: a mesocosm study. J. Plankton Res. 31:1517-1529.

Mantoura RFC, Llewellyn CA, 1983. The rapid determination of algal chlorophyll and carotenoid pigments and their breakdown products in natural waters by reverse-phase high-performance liquid chromatography. Anal. Chim. Acta. 151:297-314.

Meier PG, O'Connor D, Dilks D, 1983. Artificial substrata for reducing periphytic variability on replicated samples. Dev. Hydrob. 17:283-286.

Mitchell BG, Kiefer DA, 1984. Determination of absorption and fluorescence excitation spectra for phytoplankton, p. 157169. In: O. Holm-Hansen (ed.), Marine phytoplankton and productivity. Springer, Berlin.

Pérez GL, Torremorell A, Bustingorry J, Escaray R, Pérez P, Diéguez M, Zagarese H, 2010. Optical characteristics of shallow lakes from the Pampa and Patagonia regions of Argentina. Limnologica 40:30-39.
Quirós R, Boveri MB, Petracchi CA, Rennella AM, Rosso JJ, Sosnovsky A, von Bernard HT, 2006. [Los efectos de la agriculturización del humedal pampeano sobre la eutrofización de sus lagunas], p. 1-16. [Article in Spanish]. In: J.G. Tundizi, T. Matsumura-Tundisi and C. Sidagis Galli (eds.), Eutrofização na América do Sul: causas, conseqüèncias e tecnologías de gerenciamiento e controle. Instituto Internacional de Ecologia ed., São Carlos. Available from: www.agro.uba.ar/users/.../Eutrofizacion/Quirosetal2006EUTROSUL.pdf

Quirós R, Rennella AM, Boveri MB, Rosso JJ, Sosnovsky A, 2002. [Factores que afectan la estructura y el funcionamiento de las lagunas pampeanas]. [Article in Spanish]. Ecol. Austral 12:175-185.

Reynolds CS, 1994. The long, the short and the stalled: on the attributes of phytoplankton selected by physical mixing in lakes and rivers. Hydrobiologia 289:9-21.

Rodríguez P, Vera MS, Pizarro H (2012). Primary production of phytoplankton and periphyton in two humic lakes of a South American wetland. Limnology (in press).

Rouf AJMA, Phang SM, Ambak MA, 2010. Depth distribution and ecological preferences of periphytic algae in Kenyir Lake, the largest tropical reservoir of Malaysia. Chin. J. Oceanol. Limn. 28:856-867.

Sánchez ML, Pizarro H, Tell G, Izaguirre I, 2010. Relative importance of periphyton and phytoplankton in turbid and clear vegetated shallow lakes from the Pampa Plain (Argentina): a comparative experimental study. Hydrobiologia 646:271-280.

Scheffer M, Hosper SH, Meijer ML, Moss B, Jeppesen E, 1993. Alternative equilibria in shallow lakes. Trends Ecol. Evol. 8:275-279.

Scheffer M, Rinaldi S, Gragnani A, Mur LR, Van Ness EH, 1997. On the dominance of filamentous Cyanobacteria in shallow, turbid lakes. Ecology 78:272-282.

Shooter D, Davies-Colley RJ, Kirk JTO, 1998. Light absorption and scattering by ocean waters in the vicinity of the Chatham Rise, South Pacific Ocean. Mar. Freshwater Res. 49:455-461.

Silvoso J, Izaguirre I, Allende L, 2011. Picoplankton structure in clear and turbid eutrophic shallow lakes: a seasonal study. Limnologica 41:181-190.

Stevenson RJ, Stoermer EF, 1981. Quantitative differences between benthic algal communities along a depth gradient in Lake Michigan. J. Phycol. 17:29-36.

Stomp M, Huisman J, De Jongh F, Veraart AJ, Gerla D, Rijkeboer M, Ibelings BW, Wollenzienand UIA, Stal LJ, 2004. Adaptive divergence in pigment composition promotes phytoplankton biodiversity. Nature 432:104-107.

Tilzer MM, 1987. Light-dependence of photosynthesis and growth in cyanobacteria: implications for their dominance in eutrophic lakes. New Zeal. J. Mar. Fresh. 21:401-412.

Torremorell A, Bustingorry J, Escaray R, Zagarese H, 2007. Seasonal dynamics of a large, shallow lake, laguna Chascomús: the role of light limitation and other physical variables. Limnologica 37:100-108.

Trüper HG, Yentsch CS, 1967. Use of glass fiber filters for the rapid preparation of in vivo absorption spectra of photosynthetic bacteria. J. Bacteriol. 94:1255-1256.

Underwood AJ, 1997. Experiments in ecology: their logical design and interpretation using analysis of variance. Cambridge University Press: 509 pp.

Utermöhl M, 1958. [Zur Vervollkommung der quantitativen 
Phytoplankton Methodik]. [Article in German]. Mitt. Int. Ver. Theor. Angew. Limnol. 9:1-38.

V.-Balogh K, Németh B, Vörös L, 2009. Specific attenuation coefficients of optically active substances and their contribution to the underwater ultraviolet and visible light climate in shallow lakes and ponds. Hydrobiologia 632:91-105.

Vadeboncoeur Y, Peterson G, Vander Zanden MJ, Kalff J, 2008. Benthic algal production across lake size gradients: interactions among morphometry, nutrients, and light. Ecology 89:2542-2552.
Vadeboncoeur Y, Steinman A, 2002. Periphyton function in lake ecosystems. Sci. World J. 2:1449-1468.

Van den Hoek C, Mann DG, Jahns HM, 1998. Algae, an introduction to phycology. Cambridge University Press: 626 pp.

Venrick EL, 1978. How many cells to count? p. 167-180. In: A. Sournia (ed.), Phytoplankton Manual. UNESCO ed., Paris.

Vinocur A, O'Farrell I, Izaguirre I, 1994. Contribution to the knowledge of the diatom flora of the Salado River Basin (Buenos Aires Province, Argentina). Nova Hedwigia 58:153-175. 